\title{
Tedarik Zinciri Bütünleşmesi, Yeşil Tedarik Zinciri Uygulamaları ve İşletme Performansı Arasındaki İlişki Üzerine Bir Araştırma ${ }^{1}$
}

\author{
Dilşad Güzela ${ }^{*}$, Osman Demirdöğen ${ }^{b}$ \\ a,b Atatürk Üniversitesi, İktisadi ve İdari Bilimler Fakültesi, Erzurum.
}

\begin{abstract}
$\ddot{O} z$
Bu çalışmanın amacı, tedarik zincirinde bütünleşme, yeşil tedarik zinciri uygulamaları ve işletme performansı arasında ki ilişkinin incelenmesidir. Çalışmanın, uygulama kısmında Marmara Bölgesinde faaliyet gösteren ve Ambalaj Sanayicileri Derneğine kayıtl 102 işletmenin fabrika müdürlerine yüz yüze görüşme yöntemi ile anket uygulanmıştır. Bu doğrultuda geliştirilen hipotezler ve araştırma modeli, yapısal eşitlik modeli aracılı̆̆g ile test edilmiştir. Sonuç olarak; tedarik zinciri bütünleşmesinin, yeşil tedarik zinciri uygulamalarım, yeşil tedarik zinciri uygulamalarının da işletme performansını etkilediği tespit edilmiştir.
\end{abstract}

Anahtar Kelimeler: Yeşil tedarik zinciri, yapısal eşitlik modeli.

\section{An Investigation on the Relationship Among Supply Chain Integration, Green Supply Chain Implementations and Business Performance}

\begin{abstract}
The purpose of this study is to investigate the relationship between supply chain integration, green supply chain implementations and business performance. In the emperical part of the study, a face- to- face survey was conducted with managers of 102 plants operating in Marmara Region that are registered to Packaging Manufacturers Association. The hypothesis and the model of the study were tested with structural equation modeling. As a result, it was concluded that supply chain integration affected green supply chain implementations and green supply chain implementations affect the business performance.
\end{abstract}

Keywords: Green supply chain, structural equation models.

\section{GíRiş}

Küreselleşme ve hizla gelişen teknoloji, beraberinde artan bir rekabet ortamı getirmiştir. $\mathrm{Bu}$ durum ise, işletmelerin birbirlerine karşı olan rekabet koşullarını eskisine oranla daha zor bir hale getirmektedir. İşletmelerin bu koşullar altında rakiplerine karşı üstünlük göstermeleri, karlılıklarını artırmaları ya da maliyetlerini düşürmeleri hiç şüphesiz yenilik kavramı ile mümkün olmaktadır. Yeniliklere açık, esnek işletmeler küreselleşen dünyada kendinden söz ettirebilmekte, rakiplerine üstünlük sağlayabilmekte ve büyük pazarlarda yerlerini almaktadırlar.

Günümüzde işletmeler özellikle bu rekabet üstünlügünü sağlamak için çevre konularına yönelmişlerdir. Bu yönelim sonucunda değişik sektörlerde ki işletmeler

\footnotetext{
${ }^{1}$ Bu çalışma, Atatürk Üniversitesi Sosyal Bilimler Enstitüsü tarafından kabul edilen "Tedarik Zinciri Bütünleşmesi, Yeşil Tedarik Zinciri Uygulamaları ve İşletme Performansı Arasındaki İlişki Üzerine bir Araştırma" isimli doktora tezinden faydalanılarak oluşturulmuştur.
}

*Yazışma adresi. E-mail: dguzel@atauni.edu.tr 
çevreye duyarlı olarak mal ve hizmet üretmeye odaklanmış ve yeşil uygulamalar önem kazanmıştır.

Çevre kirliliği gibi olumsuz etkilerin insan yaşamını olumsuz yönde etkilemesi, gelecek nesilleri tehdit etmeye başlaması tüketicilerin ve devletlerin gerekli önlemler almalarını zorunlu hale getirmektedir. Bu zorunluluklar; işletmeleri ve dolayısıyla tedarik zincirlerini de etkilemektedir. Bu etkilenme sonucunda ise, işletmeler birtakım değişimler yaparak karlılığı ve verimliliği artırmak için yeşil (çevrecilik) algısını da tedarik zincirlerine adapte etmek zorunda kalmaktadırlar. Böylece sadece karlılığa dayalı tedarik zinciri kavramı yerine çevresel konuları da içeren yeşil tedarik zinciri kavramı önem kazanmaktadır.

Çalışmanın amacı, ambalaj sektöründe faaliyet gösteren işletmelerin tedarik zinciri bütünleşmelerinin yeşil tedarik zinciri uygulamaları ile ilişkisini ve yine yeşil tedarik zinciri uygulamalarının da işletme performansı ile ilişkisini ortaya koymaktır.

\section{TEDARIKK ZINCIRINNDE ÇEVRESEL İŞBIRLIIĞI VE PERFORMANS}

\subsection{Tedarikçilerle Çevresel İşbirliği}

Tedarikçilerle çevresel işbirliği, tedarikçinin çevresel performansını geliştirmek için satın alımı yapan işletme tarafından daha fazla işbirliğini ve yeşil satın alma hareketlerinin genişletilmiş halini ifade eder. Temelde tedarikçilerle çevresel işbirliği hareketleri aşağıdaki konuları içerir:

Müşterilerle Çevresel İşbirliği: Tedarikçilerle çevresel işbirliğine benzer şekilde müşterilerle çevresel işbirliği de müşterilerin çevresel performanslarını geliştirmek için işletmelerin göstermiş oldukları çabaları ifade eder. Müşterilerle çevresel işbirliği, işletme ve müşterileri arasındaki teknik bilginin değişimini içererek daha fazla yeniliği kapsayan işlemsel faydalara ve daha iyi çevresel performansa yol açar (Vachon ve Klassen, 2005: 10).

Çevresel Performans: Çevresel performans, rekabet ortamında çevresel yönetimin önemli bir faktörüdür (Cote, Lopez, Marche, Perron ve Wright, 2008: 1562). Rekabet üstünlüğü, müşteriler arasında güçlü bir imaj, maliyetlerin azaltılması gibi konularda rekabeti artırmak için işletmelere olanak sağlarken (Lopez-Gomero, MolinaAzorin ve Claver-Cortes, 2010: 966) ürün yükümlülüğü, enerji maliyetlerindeki dalgalanma ve kaynak azaltımı ile oluşan uzun dönemli riski azaltır (Shang, Lu ve Li, 2010: 1219) ve böylece işletmenin finansal performansını da olumlu yönde etkiler (Lopez-Gomero, Molina-Azorin ve Claver-Cortes, 2010: 966).

Ekonomik Performans: Yeşil tedarik zinciri uygulamaları ve ekonomik performans, gelişmekte olan ülkelerde özellikle çevresel yönetim uygulayan işletmeler için çok önemli bir faktördür. Çevresel konuların başarılması işletmelere ek değerler, yeni yollar ve rekabet için yeni fırsatlar sağlayabilir. İşletmeler arasındaki ilişkiler karlılığ1 ve yeniliği artırmada riski azaltan resmi ve resmi olmayan mekanizmalarla sağlanabilir. Yeşil tedarik zinciri boyunca malzeme alımı için maliyetleri düşürme, atıkları azaltma ve atık boşaltımı ve çevre kazaları için cezaların düşürülmesi, 
ekonomik gelişme olarak kazanılan faydalar olarak ifade edilebilir (Zhu, Sarkis, 2004: 269).

İşlemsel Performans: İşlemsel performans işletim sistemlerinin ve üretimin etkinliğini ifade eder. Genel olarak, işlemsel fonksiyonların performans amaçları ya da rekabet öncelikleri olarak ifade edilen maliyet, kalite, esneklik, güvenirlik gibi faktörlere göre değerlendirilir (Gonzalez Benito ve Gonzalez Benito, 2005: 6).Bir işletmenin işlemsel performansında yeşil tedarik zinciri girişimlerinin etkisi işlemsel sonuçlar olarak ifade edilir. İşlemsel sonuçlar esneklik ve dağıtımdaki gelişmeleri, ürün kalitesini geliştirmeyi ve maliyet azaltımını içerir.

\subsection{Tedarik Zinciri Bütünleşmesi ve Yeşil Tedarik Zinciri}

Tedarik zinciri bütünleşmesi, tedarik zinciri ortakları ile departmanlar arasındaki hareketleri bütünleştirmek için işletmenin yeteneklerini ifade eder ( $\mathrm{Li}$, Yang, Sun ve Sohal, 2009: 126). Bütünleşmenin amacı sinerjik ilişkiler ortaya çıkararak optimum seviyenin altında çalışmaktan kaçınmaktır. Teknolojik ve lojistik bütünleşme olmak üzere iki kısımda uygulanmaktadır. Teknolojik bütünleşme, yeniden yapılanma süreci, ürün geliştirme ve teknik eğitim gibi herhangi bir tedarik işletmesi ile herhangi bir satın alıcı arasında gerçekleşecek bilgi paylaşımı ve transferi olarak tarif edilirken, lojistik bütünleşme, tedarik zinciri boyunca malzeme ve bilgi akışını yönetmede işbirliği yapılmasını içerir (Vachon, 2003: 19). Yeşil tedarik zinciri yönetimi uygulamaları da bu bütünleşme ile birlikte tedarikçilerin çeşitli sertifikalara (ISO1400 ve ISO 14001 gibi) sahip olmalarını ve ürün ve malzemeleri çevresel satın almaları gibi uygulamaları kapsamaktadır (Hervani, Helms, Sarkis, 2005).

\section{TEDARIKK ZİNCİRI BÜTÜNLEŞMESI, YEŞIL TEDARÍK ZİNCİRI UYGULAMALARI VE IŞLETME PERFORMANSI ARASINDA Kİ İLIŞKİ ÜZERINE BİR ARAŞTIRMA}

\section{1. Çalışmanın Yöntemi}

Araştırmanın ana kütlesini Marmara bölgesinde faaliyet gösteren Ambalaj Sanayicileri Derneğine kayıtlı 130 sanayi kuruluşunun genel müdürleri oluşturmaktadır. Ancak bu işletmelerin sadece 102 tanesine anket uygulanabilmiştir. Söz konusu araştırma evreninin çok büyük olmamasından dolayı araştırmada tam sayım yöntemi kullanılmıştır. Dolayısı ile analizlere konu olan anket formu sayısı 102' dir. Veriler SPSS 13.0 VE LİSREL 8.7 istatistik paket programları kullanılarak analiz edilmiştir.

Bu çalışmada, Vachon'ın 2003 yılında müşterilerle ve tedarikçilerle lojistik ve teknolojik bütünleşmeyi ölçmek için kullandığı ölçekten yararlanılmıştır. Çalışmada ki yeşil tedarik zinciri uygulamaları ölçeği Vachon'ın 2003 yılında ve Zhu, Sarkis ve Lai'nın 2007 yılında yapmış oldukları çalışmalardaki ifadelerin birleştirilmesiyle oluşturulmuştur. Çalışmanın diğer boyutunu oluşturan performans ölçeği ise, Zhu, Sarkis ve Lai'nın 2008 yılında yapmış olduğu çalışmadan alınmıştır. 


\subsection{Araştırma Hipotezlerinin Oluşturulması}

Araştırmanın hipotezleri aşağıda ki gibi ifade edilebilir.

H1a: Teknolojik bütünleşme, Tedarikçi bütünleşmesini etkiler.

H1b: Lojistik bütünleşme, Tedarikçi bütünleşmesini etkiler.

H2a: Lojistik bütünleşme, müşteri bütünleşmesini etkiler.

H2b: Kaynak bütünleşmesi, müşteri bütünleşmesini etkiler.

H3a: Tedarikçi bütünleşmesi, tedarik zinciri bütünleşmesini etkiler.

H3b: Müşteri bütünleşmesi, tedarik zinciri bütünleşmesini etkiler.

H4: Tedarik zinciri bütünleşmesi, yeşil tedarik zinciri uygulamalarını etkiler.

H5a: Müşterilerle çevresel işbirliği, müşterilere ilişkin yeşil tedarik zinciri uygulamalarını etkiler.

H5b: Müşterilerle çevresel hareketler, müşterilere ilişkin yeşil tedarik zinciri uygulamaların etkiler.

H5c: Müşterilerle çevresel yönetim, müşterilere ilişkin yeşil tedarik zinciri uygulamalarını etkiler.

H6a: Tedarikçilerle çevresel işbirliği, tedarikçilere ilişkin yeşil tedarik zinciri uygulamalarını etkiler.

H6b: Tedarikçilerle çevresel hareketler, tedarikçilere ilişkin yeşil tedarik zinciri uygulamalarını etkiler.

H6c: Tedarikçilerle çevresel yönetim, tedarikçilere ilişkin yeşil tedarik zinciri uygulamalarını etkiler.

H7: Yeşil tedarik zinciri uygulamaları işletme performansını etkiler.

H8: Çevresel performans işletme performansını etkiler.

H9: Ekonomik performans işletme performansını etkiler.

H10: İşlemsel performans işletme performansını etkiler

Yukarıdaki hipotezler ışığında test edilecek araştırma modeli Şekil 1'de görülmektedir. 


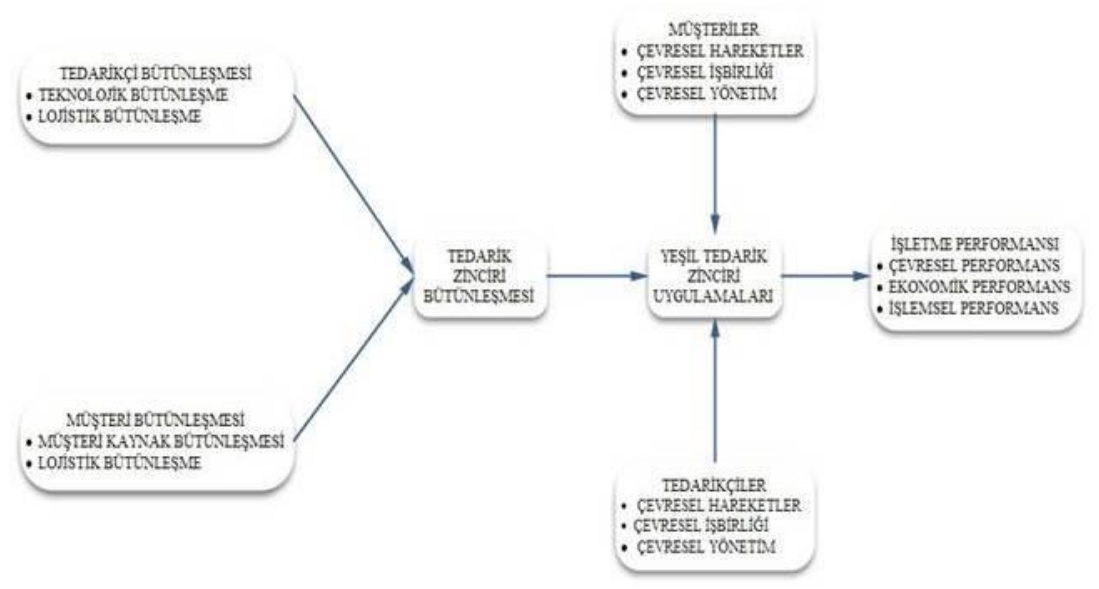

Şekil 1. Araştırmanın Modeli

\subsection{ARAŞTIRMADA KULLANILAN ÖLÇEKLERIN TEST EDİLMESI}

\subsubsection{Tedarikçilerle Lojistik Bütünleşme Ölçeğinin Testi}

Araştırmada kullanılan tedarikçilerle lojistik bütünleşme ölçeğini oluşturan boyutlar ayrı ayrı doğrulayıcı faktör analizine tabi tutulmuştur. Doğrulayıcı faktör analizi sonucu uyum değerleri kabul edilebilir sınırlar içerisinde olduğu için modifikasyon yapılmamıştır. Analiz sonucu elde edilen uyum değerleri Tablo 1'de gösterilmiştir.

Tablo 1. Tedarikçilerle Lojistik Bütünleşme Ölçeğinin Uyum Değerleri

\begin{tabular}{|c|c|c|c|}
\hline Uyumluluk İndeksi & Değerler & Uyumluluk İndeksi & Değerler \\
\hline Ki-Kare $\left(\mathrm{X}^{2}\right)$ & 7.70 & RMSEA & 0.073 \\
\hline Serbestlik Derecesi & 5 & CFI & 0.99 \\
\hline Ki-Kare/sd & 1.54 & NNFI & 0.98 \\
\hline GFI & 0.97 & NFI & 0.97 \\
\hline AGFI & 0.91 & RMSR & 0.030 \\
\hline
\end{tabular}

Sonuçlara göre Ki-Kare/sd 1.54 ve ortalama hata karekökü RMSEA 0.073 olup kabul edilebilir sınırlar içerisindedir. Düzeltilmiş uyum indeksi (AGFI) değeri 0.91 ve karşılaştırmalı uyum indeksi (CFI) değeri 0.99 olup iyi düzeydedir. Tedarikçilerle Lojistik Bütünleşme ile ilgili yapılan doğrulayıcı faktör analizi sonucu elde edilen değişkenler Tablo 3'de gösterilirken ölçeğin boyutlarını oluşturan değişkenlerin standart katsayıları, hata varyansları ve $\mathrm{t}$ değerleri Tablo 2' de gösterilmiştir. 
Tablo 2. Tedarikçilerle Lojistik Bütünleşme Ölçek Testi Sonrası Kalan Değişkenleri

\begin{tabular}{|l|c|c|c|c|}
\hline \multicolumn{1}{|c|}{ Değişkenler } & S.Değer & $\mathbf{R}^{2}$ & H.Varyansi & t Değeri \\
\hline $\begin{array}{l}\text { Birincil tedarikçilerimizin ilerlemesine yardım } \\
\text { edecek bilgileri sağlar -İ1 }\end{array}$ & 0.67 & 0.45 & 0.50 & 6.90 \\
\hline $\begin{array}{l}\text { Birincil tedarikçileriyle operasyonel ve lojistikle } \\
\text { ilgili bilgi alış verişinde bulunur-İ2 }\end{array}$ & 0.69 & 0.48 & 0.34 & 7.17 \\
\hline $\begin{array}{l}\text { Önceden belirlenmiş bir anlaşma olmadan birincil } \\
\text { tedarikçileriyle gayri resmi olarak bilgi alış } \\
\text { verişinde bulunur-İ3 }\end{array}$ & 0.66 & 0.44 & 0.52 & 6.77 \\
\hline $\begin{array}{l}\text { Birincil tedarikçilerimizi etkileyebilecek olan olay } \\
\text { ve değişiklikleri onlara bildirir-İ4 }\end{array}$ & 0.65 & 0.42 & 0.44 & 6.65 \\
\hline $\begin{array}{l}\text { Birincil tedarikçilerimizle planlama yapma amacı } \\
\text { ile yüz yüze iletişimde bulunur-İ5 }\end{array}$ & 0.73 & 0.54 & 0.44 & 7.73 \\
\hline
\end{tabular}

Değerler incelendiğinde standart değerlerin $0.98^{\prime}$ den küçük, $t$ değerlerinin ise 2'den büyük olması yine $\mathrm{R}^{2}$ ve hata varyans değerleri ölçeğin uyumlu olduğunu göstermektedir.

\subsubsection{Tedarikçilerle Teknolojik Bütünleşme Ölçeğinin Testi}

Tedarik zinciri bütünleşme boyutlarında tedarikçilerle teknolojik bütünleşme ölçeğini test etmek amacıyla, doğrulayıcı faktör analizi yapılmıştır. Doğrulayıcı faktör analizi sonucu tedarikçilerle teknolojik bütünleşme altında yer alan 7 değişkene ait model uyum değerlerinin kabul edilebilir düzeyde olmadıkları görülmüştür. Analiz sonucunda önerilen modifikasyonlar yapılmış, modifikasyon öncesi ve sonrası model uyum değerleri Tablo 3'de gösterilmiştir.

Tablo 3. Tedarikçilerle teknolojik Bütünleşme Ölçeğinin Uyum Değerleri

\begin{tabular}{|c|c|c|c|c|c|}
\hline Uyum İndeksi & Mod.Öncesi & Mod.Sonras1 & Uyum İndeksi & Mod.Öncesi & Mod. Sonras1 \\
\hline \multicolumn{6}{|c|}{ Mutlak Uyum Değeri } \\
\hline Ki-Kare $\left(\mathrm{X}^{2}\right)$ & 42.41 & 1.6 & AGFI & 0.79 & 0.96 \\
\hline $\begin{array}{l}\text { Serbestlik } \\
\text { Derecesi }\end{array}$ & 14 & 2 & RMSR & 0.05 & 0020 \\
\hline Ki-Kare/sd & 3.029 & 0.8 & RMSEA & 0.142 & 0.00 \\
\hline GFI & 0.89 & 0.9 & & & \\
\hline \multicolumn{6}{|c|}{ Artan Uyum Değeri } \\
\hline CFI & 0.94 & 1 & NFI & 0.92 & 0.99 \\
\hline NNFI & 0.91 & 1 & & & \\
\hline
\end{tabular}


Doğrulayıcı faktör analizi sonuçlarına göre, 7 değişkenin yer aldığ tedarikçilerle teknolojik bütünleşmeye ait model uyum değerlerinden GFI (0.89), AGFI (0.79), CFI (0.94), NNFI (0.91), NFI (0.92) model uyumluluğu için kabul edilebilir düzeyde değildir. $\mathrm{Bu}$ nedenle, analiz sonucu önerilen modifikasyonlar yapılmış, istatistiki bakımdan uygun olmayan 3 (B3,B5,B7) değişken elenmiştir. Karşılaştırmalı uyum indeksi (CFI)'nin ve Normlaştırılmamış Uyum İndeksi (NNFI)'nın değeri 1.00 olup, kabul edilebilirliği iyi düzeydedir. Düzeltilmiş uyum indeksi (AGFI) 0.96 olup, model uyumluluğu için istatistiki bakımdan yeterlidir. GFI (0.99) ve NFI (0.99) ise kabul edilebilir düzeydedir. Bu değerlere göre, tedarikçilerle teknolojik bütünleşme altında yer alan değişkenlerin kabul edilebilirliği oldukça iyi düzeydedir.

Tedarikçilerle teknolojik bütünleşme ile ilgili yapılan doğrulayıcı faktör analizi sonucu kalan değişkenlerin değerleri Tablo 4'de gösterilmiştir.

Tablo 4. Tedarikçilerle teknolojik bütünleşme ölçek testi sonrası kalan değişkenleri

\begin{tabular}{|l|c|c|c|c|}
\hline \multicolumn{1}{|c|}{ Değişkenler } & $\begin{array}{c}\text { Standart } \\
\text { Değer }\end{array}$ & $\mathbf{R}^{2}$ & $\begin{array}{c}\text { Hata } \\
\text { Varyansı }\end{array}$ & $\mathbf{t}$ Değeri \\
\hline $\begin{array}{l}\text { Performansımızın artmasına yardım etmek için } \\
\text { tesislerimizi ziyaret ederler-B1 }\end{array}$ & 0.73 & 0.54 & 0.39 & 7.61 \\
\hline $\begin{array}{l}\text { Bize sadece ürünlerini değil, aynı zamanda } \\
\text { yeteneklerini de satarlar-B2 }\end{array}$ & 0.79 & 0.63 & 0.35 & 8.32 \\
\hline $\begin{array}{l}\text { Sattıkları ürünleri hakkında eğitim verirler-B4 } \\
\begin{array}{l}\text { Onlardan sipariş ettiğimiz ürünlerin kalitesini } \\
\text { geliştirmek için bizimle beraber gayret gösterirler- } \\
\text { B6 }\end{array}\end{array} \quad 0.64$ & 0.63 & 0.39 & 0.57 & 6.31 \\
\hline
\end{tabular}

Değerler incelendiğinde standart değerlerin $0.98^{\prime}$ den küçük, $t$ değerlerinin ise 2 'den büyük olması yine $\mathrm{R}^{2}$ ve hata varyans değerleri, ölçeğin uyumlu olduğunu göstermektedir.

\subsubsection{Müşterilerle Kaynak Bütünleşmesi Ölçeğinin Testi}

Tedarik zinciri bütünleşme boyutlarından müşterilerle kaynak bütünleşmesi ölçeğini test etmek amacıyla, doğrulayıcı faktör analizi yapılmıştır. Doğrulayıcı faktör analizi sonucu uyum değerleri kabul edilebilir sınırlar içerisinde olduğu için modifikasyon yapılmamıştır. Analiz sonucu elde edilen uyum değerleri Tablo 5'de gösterilmiştir. 
Tablo 5. Müşterilerle Kaynak Bütünleşmesi Ölçeğinin Uyum Değerleri

\begin{tabular}{|c|c|c|c|}
\hline Uyumluluk İndeksi & Uyum değerleri & Uyumluluk İndeksi & Uyum değerleri \\
\hline $\begin{array}{l}\text { Ki-Kare } \\
\left(X^{2}\right)\end{array}$ & 0.70 & CFI & 1 \\
\hline $\begin{array}{l}\text { Serbestlik } \\
\text { Derecesi }\end{array}$ & 2 & NNFI & 1 \\
\hline Ki-Kare/sd & 0.35 & NFI & 0.99 \\
\hline GFI & 1 & RMSR & 0.012 \\
\hline AGFI & 0.98 & RMSEA & 0.0 \\
\hline
\end{tabular}

Sonuçlara göre, Düzeltilmiş uyum indeksi (AGFI), değeri 0.98, GFI ise 1.00, Artmalı uyum indeksi (CFI) 1.00, Normlaştırılmamış Uyum İndeksi (NNFI) 1.00, Normlaştırılmış Uyum İndeksi (NFI) 0.99 olup kabul edilebilirlikleri iyi düzeydedir. Müşterilerle kaynak bütünleşmesi ile ilgili yapılan doğrulayıcı faktör analizi sonucu kalan değişkenlerin değerleri Tablo 6 'da gösterilmiştir.

Tablo 6. Müşterilerle Kaynak Bütünleşmesi Ölçek Testi Doğrulayıcı Faktör Analizi Sonucu Elde Edilen Değerler

\begin{tabular}{|l|c|c|c|c|}
\hline \multicolumn{1}{|c|}{ Değişkenler } & S.Değer & $\mathbf{R}^{2}$ & H.Varyansı & t Değeri \\
\hline Personelimize eğitim imkanı sağlarlar-B11 & 0.70 & 0.49 & 0.45 & 6.96 \\
\hline $\begin{array}{l}\text { Performansımızın artmasına yardım etmek için } \\
\text { tesislerimizi ziyaret ederler-B12 }\end{array}$ & 0.75 & 0.56 & 0.29 & 7.43 \\
\hline $\begin{array}{l}\text { Ürünlerimizin nasıl kullanıldığını göstermek } \\
\text { için bizi tesislerine davet ederler-B13 }\end{array}$ & 0.65 & 0.42 & 0.53 & 6.35 \\
\hline $\begin{array}{l}\text { Basım sürecine katılırlar ve basımın ilk } \\
\text { aşamalarında bize yardımcı olurlar-B14 }\end{array}$ & 0.57 & .32 & 0.51 & 5.47 \\
\hline
\end{tabular}

Değerler incelendiğinde standart değerlerin $0.98^{\prime}$ den küçük, $t$ değerlerinin ise 2 'den büyük olması yine $\mathrm{R}^{2}$ ve hata varyans değerleri, ölçeğin uyumlu olduğunu göstermektedir.

\subsubsection{Müşterilerle Lojistik Bütünleşme Ölçeğinin Testi}

Tedarik zinciri bütünleşme boyutlarından müşterilerle lojistik bütünleşme ölçeğini test etmek amacıyla, doğrulayıcı faktör analizi yapılmıştır. Doğrulayıcı faktör analizi sonucu müşterilerle lojistik bütünleşme altında yer alan 8 değişkene ait model uyum değerlerinin kabul edilebilir düzeyde olmadıkları görülmüştür. Analiz sonucunda önerilen modifikasyonlar yapılmış, modifikasyon öncesi ve sonrası model uyum değerleri Tablo 7'de gösterilmiştir. 
Tablo 7. Müşterilerle lojistik Bütünleşme Ölçeğinin Uyum Değerleri

\begin{tabular}{|l|c|c|c|c|c|}
\hline \multicolumn{1}{|c|}{ Uyum İndeksi } & Mod.Öncesi & Mod.Sonrası & $\begin{array}{c}\text { Uyum } \\
\text { İndeksi }\end{array}$ & Mod.Öncesi & Mod. Sonrasi \\
\hline \multicolumn{2}{|l|}{ Mutlak Uyum Değeri } & & & & \\
\hline Ki-Kare $\left(X^{2}\right)$ & 64.56 & 0.51 & AGFI & 0.75 & 0.99 \\
\hline $\begin{array}{l}\text { Serbestlik } \\
\text { Derecesi }\end{array}$ & 20 & 2 & RMSR & 0.059 & 0.0096 \\
\hline Ki-Kare/sd & 3.228 & 0.25 & RMSEA & 0.149 & 0.00 \\
\hline GFI & 0.86 & 1 & & & \\
\hline Artan Uyum Değeri & 0.93 & 1 & NFI & 0.90 & 1 \\
\hline CFI & 0.91 & 1 & & & \\
\hline NNFI & & 1 & & & \\
\hline
\end{tabular}

Doğrulayıcı faktör analizi sonuçlarına göre, 8 değişkenin yer aldığ1 tedarikçilerle lojistik bütünleşmeye ait model uyum değerlerinden uyum iyiliği indeksi GFI (0.86), düzeltilmiş uyum indeksi AGFI (0.75), karşılaştırmalı uyum indeksi CFI (0.93), normlaştırılmamış uyum indeksi NNFI (0.91), normlaştırılmış uyum indeksi NFI (0.90) model uyumluluğu için kabul edilebilir düzeyde değildir. Bu nedenle, analiz sonucu önerilen modifikasyonlar yapılmış, istatistiki bakımdan uygun olmayan 4(B21, B22, B26, B28) değişken elenmiştir. Sonuçlara göre karşılaştırmalı uyum indeksi (CFI)'nin değeri 1.00 olup, kabul edilebilirliği iyi düzeydedir. Düzeltilmiş uyum iyiliği indeksi (AGFI) 0.99 olup, model uyumluluğu için istatistiki bakımdan yeterlidir. Normlaştırılmamış uyum indeksi (NNFI), karşılaştırmalı uyum indeksi (CFI), normlaştırılmış uyum indeksi (NFI) değerleri ise, 1 eşit olup kabul edilebilir düzeydedir. Bu değerlere göre, müşterilerle lojistik bütünleşme ölçeğinin altında yer alan değişkenlerin kabul edilebilirliği iyi düzeydedir. Müşterilerle lojistik bütünleşme ile ilgili yapılan doğrulayıcı faktör analizi sonucu kalan değişkenlerin değerleri Tablo 8'de gösterilmiştir. 
Tablo 8. Müşterilerle Lojistik Bütünleşme Ölçek Testi Sonrası Kalan Değişkenleri

\begin{tabular}{|l|c|c|c|c|}
\hline \multicolumn{1}{|c|}{ Değişkenler } & S. Değer & $\mathbf{R}^{2}$ & H.Varyansı & t Değeri \\
\hline $\begin{array}{l}\text { Mevcut ambalajlamadaki önemli dizayn } \\
\text { değişiklikleriyle ilgili üretim konularını bizimle } \\
\text { müzakere ederler-B23 }\end{array}$ & 0.76 & 0.58 & 0.29 & 8.11 \\
\hline $\begin{array}{l}\text { Bizimle özel bir anlaşma olmadan gayri resmi } \\
\text { olarak bilgi alış verişinde bulunur-B24 }\end{array}$ & 0.83 & 0.68 & 0.30 & 8.93 \\
\hline $\begin{array}{l}\text { Bizimle planlama yapma amacı ile yüz yüze } \\
\text { iletişimde bulunur-B25 }\end{array}$ & 0.57 & 0.32 & 0.64 & 5.64 \\
\hline $\begin{array}{l}\text { Ürün sevkiyatı ile ilgili isteklerde esnekliğe izin } \\
\text { verirler-B27 }\end{array}$ & 0.66 & 0.44 & 0.54 & 6.85 \\
\hline
\end{tabular}

Değerler incelendiğinde standart değerlerin 0.98' den küçük, $t$ değerlerinin ise 2 'den büyük olması yine $\mathrm{R}^{2}$ ve hata varyans değerleri, ölçeğin uyumlu olduğunu göstermektedir.

\subsubsection{Tedarikçilerin Çevresel Hareketleri Ölçeğinin Testi}

Yeşil tedarik zinciri boyutlarından tedarikçilerin çevresel hareketleri ölçeğini test etmek amacıyla, doğrulayıcı faktör analizi yapılmıştır. Doğrulayıcı faktör analizi sonucu tedarikçilerin çevresel hareketleri altında yer alan 10 değişkene ait model uyum değerlerinin kabul edilebilir düzeyde olmadıkları görülmüştür. Analiz sonucunda önerilen modifikasyonlar yapılmış, modifikasyon öncesi ve sonrası model uyum değerleri Tablo 9'da gösterilmiştir.

Tablo 9. Tedarikçilerin Çevresel Hareketleri Ölçeğinin Uyum Değerleri

\begin{tabular}{|l|c|c|c|c|c|}
\hline Uyum İndeksi & Mod.Öncesi & Mod.Sonras1 & Uyum İndeksi & Mod.Öncesi & Mod. Sonrası \\
\hline Ki-Kare & 107.76 & 13.92 & RMSR & 0.068 & 0.038 \\
\hline $\begin{array}{l}\text { Serbestlik } \\
\text { Derecesi }\end{array}$ & 35 & 9 & RMSEA & 0.143 & 0.074 \\
\hline Ki-Kare/sd & 3.078 & 1.54 & CFI & 0.92 & 0.98 \\
\hline GFI & 0.82 & 0.96 & NNFI & 0.90 & 0.97 \\
\hline AGFI & 0.72 & 0.90 & NFI & 0.89 & 0.96 \\
\hline
\end{tabular}

Doğrulayıcı faktör analizi sonuçlarına göre, 10 değişkenin yer aldığı tedarikçilerin çevresel hareketlerine ait model uyum değerlerinden Uyum iyiliği indeksi GFI (0.82), Düzeltilmiş uyum İndeksi AGFI (0.72), Ortalama hata karekök yaklaşımı RMSEA (0.143), Karşılaştırmalı uyum indeksi CFI (0.92), Normlaştırılmamış uyum indeksi NNFI (0.90), Normlaştırılmış uyum indeksi NFI (0.89) model uyumluluğu için kabul edilebilir düzeyde değildir. Bu nedenle, analiz sonucu önerilen 
modifikasyonlar yapılmış, istatistiki bakımdan uygun olmayan 4(D12, D14, D15, D110) değişken elenmiştir.

Artmalı uyum indeksi (CFI)' nin değeri 0.98 olup, kabul edilebilirliği iyi düzeydedir. Düzeltilmiş uyum iyiliği indeksi (AGFI) 0.90 olup, model uyumluluğu için istatistiki bakımdan yeterlidir. 0.08 ya da daha az olması önerilen RMSA değeri 0.074 dür. Bu değerlere göre, tedarikçilerin çevresel hareketleri altında yer alan değişkenlerin kabul edilebilirliği iyi düzeydedir. Tedarikçilerin çevresel hareketleri ile ilgili yapılan doğrulayıcı faktör analizi sonucu kalan değişkenlerin değerleri Tablo 10 'da gösterilmiştir.

Tablo 10. Tedarikçilerin Çevresel Hareketleri Ölçek Testi Sonrası Kalan Değişkenleri

\begin{tabular}{|l|c|c|c|c|}
\hline \multicolumn{1}{|c|}{ Değişkenler } & S.Değer & $\mathbf{R}^{2}$ & H.Varyansi & t Değeri \\
\hline $\begin{array}{l}\text { Çevre yönetimi ve teknolojilerindeki bilgi ve } \\
\text { uzmanlıklarını paylaşırlar-D11 }\end{array}$ & 0.56 & 0.32 & 0.61 & 5.80 \\
\hline $\begin{array}{l}\text { Daha fazla çevre dostu olan malzemeler } \\
\text { kullanımına geçiş aşamasına yardımcı olurlar } \\
\text { (örneğin, mürekkep değişimi, su bazlı } \\
\text { yapıştırıcı)-D13 }\end{array}$ & 0.56 & 0.31 & 0.63 & 5.72 \\
\hline $\begin{array}{l}\text { Çevresel ambalajlama uygulamalarında işbirliği } \\
\text { yaparlar-D16 }\end{array}$ & 0.83 & 0.69 & 0.26 & 9.70 \\
\hline $\begin{array}{l}\text { Çevresel pazarlama uygulamalarında işbirliği } \\
\text { yaparlar-D17 }\end{array}$ & 0.80 & 0.64 & 0.25 & 9.18 \\
\hline $\begin{array}{l}\text { Ürün dizaynın da üretim sürecinde ki tehlikeli } \\
\text { ürünlerin kullanımını azaltmak için işbirliği } \\
\text { yaparlar-D18 }\end{array}$ & 0.74 & .55 & 0.42 & 8.23 \\
\hline $\begin{array}{l}\text { Ürün dizaynın da enerji tüketimini azaltmak için } \\
\text { işbirliği yaparlar-D19 }\end{array}$ & 0.59 & 0.34 & 0.62 & 6.08 \\
\hline
\end{tabular}

Değerler incelendiğinde standart değerlerin $0.98^{\prime}$ den küçük, $t$ değerlerinin ise 2 'den büyük olması yine $R^{2}$ ve hata varyans değerleri, ölçeğin uyumlu olduğunu göstermektedir.

\subsubsection{Tedarikçilerle Çevresel işbirliği Ölçeğinin Testi}

Araştırmada kullanılan “Tedarikçilerle Çevresel işbirliği” ölçeğini oluşturan boyutlar ayrı ayrı doğrulayıcı faktör analizine tabi tutulduktan sonra 5 değişkene ait model uyum değerlerinin kabul edilebilir sınırlar içerisinde olmadığ Analiz sonucunda önerilen modifikasyonlar yapılmış, modifikasyon öncesi ve sonrası model uyum değerleri Tablo 11'de gösterilmiştir. Doğrulayıc1 faktör analizi sonuçlarına göre ortalama hataların karekökü RMSR (0.03) kabul edilebilir sınırlar içerisinde değildir. Bu nedenle, analiz sonucu önerilen modifikasyonlar yapılmış, istatistiki bakımdan uygun olmayan 1 (D22) değişken elenmiştir. 
Tablo 11. Tedarikçilerle Çevresel İşbirliği Ölçeğinin Uyum Değerleri

\begin{tabular}{|l|c|c|c|c|c|}
\hline \multicolumn{1}{|c|}{ Uyum İndeksi } & Mod.Öncesi & Mod.Sonrasi & Uyum İndeksi & Mod.Öncesi & Mod.Sonras1 \\
\hline Ki-Kare $\left(X^{2}\right)$ & 7.70 & 1.33 & RMSR & 0.0 & 0.05 \\
\hline S. Derecesi & 5 & 2 & RMSEA & 0.073 & 0.00 \\
\hline Ki-Kare/sd & 1.54 & & CFI & 0.99 & 1 \\
\hline GFI & 0.97 & 0.99 & NNFI & 0.98 & 1 \\
\hline AGFI & 0.91 & 0.97 & NFI & 0.97 & 0.99 \\
\hline
\end{tabular}

Sonuçlara göre, Düzeltilmiş uyum indeksi (AGFI) değeri 0.97, Normlaştırılmamış uyum indeksi (NNFI), 1 ve karşılaştırmalı uyum indeksi (CFI) değeri 1 olup iyi düzeydedirler. Tedarikçilerle çevresel işbirliği ile ilgili yapılan doğrulayıcı faktör analizi sonucu elde edilen değişkenler Tablo 11'de gösterilirken ölçeğin boyutlarını oluşturan değişkenlerin standart katsayıları, hata varyansları ve $t$ değerleri Tablo 12' de gösterilmiştir.

Tablo 12. Tedarikçilerle Çevresel İşbirliği Ölçek Testi Sonrası Kalan Değişkenler

\begin{tabular}{|l|c|c|c|c|}
\hline \multicolumn{1}{|c|}{ Değişkenler } & S.Değer & $\mathbf{R}^{2}$ & H.Varyans1 & t Değeri \\
\hline Çevresel hedefleri ortaklaşa başarmak-D21 & 0.67 & 0.45 & 0.50 & 6.90 \\
\hline $\begin{array}{l}\text { Faaliyetlerimizin çevreye olan etkisini azaltmak } \\
\text { için birlikte çalışmak-D23 }\end{array}$ & 0.66 & 0.44 & 0.52 & 6.77 \\
\hline $\begin{array}{l}\text { Çevreyle ilgili problemlerin tahmini ve çözümü } \\
\text { için ortaklaşa planlama yapmak-D24 }\end{array}$ & 0.65 & 0.42 & 0.44 & 6.65 \\
\hline $\begin{array}{l}\text { Ürünlerimizin çevresel etkilerini azaltmak için } \\
\text { ortaklaşa karar vermek-D25 }\end{array}$ & 0.73 & 0.54 & 0.44 & 7.73 \\
\hline
\end{tabular}

Değerler incelendiğinde standart değerlerin 0.98 den küçük, $t$ değerlerinin ise 2 'den büyük olması yine $\mathrm{R}^{2}$ ve hata varyans değerleri, ölçeğin uyumlu olduğunu göstermektedir.

\subsubsection{Tedarikçilerin Çevresel Yönetim Ölçeğinin Testi}

Araştırmada kullanılan yeşil tedarik zinciri boyutlarından tedarikçilerin çevresel yönetim ölçeğini oluşturan boyutlar ayrı ayrı doğrulayıcı faktör analizine tabi tutulduktan sonra doğrulayıcı faktör analizi sonucu uyum değerleri kabul edilebilir sınırlar içerisinde olduğu için modifikasyon yapılmamıştır. Analiz sonucu elde edilen uyum değerleri Tablo 13' de gösterilmiştir. 
Tablo 13. Tedarikçilerin Çevresel Yönetim Ölçeğinin Uyum Değerleri

\begin{tabular}{|l|c|c|c|c|c|}
\hline \multicolumn{1}{|c|}{$\begin{array}{c}\text { Uyumluluk } \\
\text { İndeksi }\end{array}$} & Değerler & $\begin{array}{c}\text { Uyumlulu } \\
\text { k İndeksi }\end{array}$ & Değerler & $\begin{array}{c}\text { Uyumlulu } \\
\text { k İndeksi }\end{array}$ & Değerler \\
\hline Ki-Kare $\left(\mathrm{X}^{2}\right)$ & 7.62 & CFI & 0.99 & GFI & 0.97 \\
\hline $\begin{array}{l}\text { Serbestlik } \\
\text { Derecesi }\end{array}$ & 5 & NNFI & 0.98 & AGFI & 0.91 \\
\hline Ki-Kare/sd & 1.52 & NFI & 0.96 & RMSR & 0.05 \\
\hline & & & & RMSEA & 0.072 \\
\hline
\end{tabular}

Sonuçlara göre Ki-Kare/sd 1.52 ve ortalama hata karekökü RMSEA 0.072 olup kabul edilebilir sınırlar içerisindedir. Düzeltilmiş uyum indeksi (AGFI) değeri 0.91 ve karşılaştırmalı uyum indeksi (CFI) değeri 0.99 olup iyi düzeydedirler. Yeşil tedarik zinciri boyutlarından tedarikçilerin çevresel yönetim ile ilgili yapılan doğrulayıcı faktör analizi sonucu elde edilen değişkenler Tablo 13'de gösterilirken ölçeğin boyutlarını oluşturan değişkenlerin standart katsayıları, hata varyansları ve t değerleri Tablo 14'de gösterilmiştir.

Tablo 14. Tedarikçilerin Çevresel Yönetimi Ölçek Testi Sonrası Kalan Değişkenleri

\begin{tabular}{|l|c|c|c|c|}
\hline \multicolumn{1}{|c|}{ Değişkenler } & S.Değer & $\mathbf{R}^{2}$ & H.Varyansi & t Değeri \\
\hline $\begin{array}{l}\text { Tedarikçi seçimi kriterinde çevresel faktörleri } \\
\text { dikkate almak-D31 }\end{array}$ & 0.57 & 0.32 & 0.63 & 5.68 \\
\hline $\begin{array}{l}\text { Tedarikçilere yazılı çevresel istekleri bildirmek- } \\
\text { D32 }\end{array}$ & 0.63 & 0.40 & 0.59 & 6.51 \\
\hline $\begin{array}{l}\text { Tedarikçilere uygunluklarını gözlemlemek için } \\
\text { çevreyle ilgili anketler yollamak-D33 }\end{array}$ & 0.81 & 0.66 & 0.31 & 8.91 \\
\hline $\begin{array}{l}\text { Tedarikçilerin uygulanmakta olan çevresel } \\
\text { yönetim sistemine sahip olmalarını istemek-D34 }\end{array}$ & 0.75 & 0.57 & 0.33 & 8.06 \\
\hline $\begin{array}{l}\text { Tedarikçilerin atık azaltma hedeflerine sahip } \\
\text { olmalarını istemek-D35 }\end{array}$ & 0.59 & 0.35 & 0.42 & 5.96 \\
\hline
\end{tabular}

Değerler incelendiğinde standart değerlerin $0.98^{\prime}$ den küçük, $t$ değerlerinin ise $2^{\prime}$ den büyük olması yine $R^{2}$ ve hata varyans değerleri, ölçeğin uyumlu olduğunu göstermektedir.

\subsubsection{Müşteriler Arasında ki Çevresel Hareketler Ölçeğinin Testi}

Yeşil tedarik zinciri boyutlarından müşterilerin çevresel hareketleri ölçeğini test etmek amacıyla, doğrulayıcı faktör analizi yapılmıştır. Doğrulayıcı faktör analizi sonucu müşterilerin çevresel hareketleri altında yer alan 10 değişkenin model uyum değerlerinin kabul edilebilir düzeyde olmadıkları görülmüştür. Analiz sonucunda 
önerilen modifikasyonlar yapılmış, modifikasyon öncesi ve sonrası model uyum değerleri Tablo 15'de gösterilmiştir.

Tablo 15. Müşteri çevresel hareket Ölçeğinin Uyum Değerleri

\begin{tabular}{|c|c|c|c|c|c|}
\hline Uyum İndeksi & Mod.Öncesi & Mod.Sonras1 & Uyum İndeksi & Mod.Öncesi & Mod. Sonrası \\
\hline \multicolumn{6}{|c|}{ Mutlak Uyum Değeri } \\
\hline Ki-Kare $\left(X^{2}\right)$ & 107.76 & 13.92 & GFI & 0.82 & 0.96 \\
\hline $\begin{array}{l}\text { Serbestlik } \\
\text { Derecesi }\end{array}$ & 35 & 9 & AGFI & 0.72 & 0.90 \\
\hline \multirow[t]{2}{*}{$\mathrm{Ki}$-Kare/sd } & 3.078 & 1.54 & RMSR & 0.068 & 0.038 \\
\hline & & & RMSEA & 0.143 & 0.074 \\
\hline \multicolumn{6}{|c|}{ Artan Uyum Değeri } \\
\hline CFI & 0.92 & 0.98 & NFI & 0.89 & 0.96 \\
\hline NNFI & 0.90 & 0.97 & & & \\
\hline
\end{tabular}

Doğrulayıcı faktör analizi sonuçlarına göre, 10 değişkenin yer aldığ müşterilerin çevresel hareketlerine ait model uyum değerlerinden GFI (0.82), AGFI (0.72), RMSEA (0.143), CFI (0.92), NNFI (0.90), NFI (0.89) uyumluluğu için kabul edilebilir düzeyde değildir. $\mathrm{Bu}$ nedenle, analiz sonucu önerilen modifikasyonlar yapılmış, istatistiki bakımdan uygun olmayan 4(e12,e14,e15,e110) değişken elenmiştir. Sonuçlara göre, 13.92 ki kare değeri ve 9 serbestlik derecesinin birbirine oranı 1.54 olup, 5'in altında olması nedeniyle istatistiki bakımdan kabul edilebilir bir değere sahiptir. Uyum iyiliği indeksi (GFI), normlaştırılmış uyum indeksi(NFI) 0.96 ve Karşılaştırmalı uyum indeksi (CFI), 0.98 olup iyi düzeydedirler. Düzeltilmiş uyum İndeksi (AGFI), 0.90, model uyumluluğu için istatistiki anlamda yeterlidir. Müşterilerin çevresel hareketleri ile ilgili yapılan doğrulayıcı faktör analizi sonucu kalan değişkenlerin değerleri Tablo 16' da gösterilmiştir. 
Tablo 16. Müşterilerin Çevresel Hareketleri Ölçek Testi Sonrası Kalan Değişkenleri

\begin{tabular}{|l|c|c|c|c|}
\hline \multicolumn{1}{|c|}{ Değişkenler } & S.Değer & $\mathbf{R}^{2}$ & H. Varyansi & t Değeri \\
\hline $\begin{array}{l}\text { Çevresel yönetim ve teknolojiler konusunda bilgi } \\
\text { ve deneyimlerini paylaşırlar-E11 }\end{array}$ & 0.56 & 0.32 & 0.61 & 5.80 \\
\hline $\begin{array}{l}\text { Çevreye duyarlı malzeme alma sürecinde } \\
\text { uzmanlık sağlar-E13 }\end{array}$ & 0.56 & 0.31 & 0.63 & 5.72 \\
\hline $\begin{array}{l}\text { Çevresel ambalajlama uygulamalarında işbirliği } \\
\text { yaparlar-E16 }\end{array}$ & 0.83 & 0.69 & 0.26 & 9.70 \\
\hline $\begin{array}{l}\text { Çevresel pazarlama uygulamalarında işbirliği } \\
\text { yaparlar-E17 }\end{array}$ & 0.80 & 0.64 & 0.25 & 9.18 \\
\hline $\begin{array}{l}\text { Ürün dizaynın da üretim sürecinde ki tehlikeli } \\
\text { ürünlerin kullanımını azaltmak için işbirliği-E18 }\end{array}$ & 0.74 & 0.55 & 0.42 & 8.23 \\
\hline $\begin{array}{l}\text { Ürün dizaynın da enerji tüketimini azaltmak için } \\
\text { işbirliği yaparlar-E19 }\end{array}$ & 0.59 & 0.34 & 0.62 & 6.08 \\
\hline
\end{tabular}

Değerler incelendiğinde standart değerlerin 0.98 den küçük, $t$ değerlerinin ise 2 'den büyük olması yine $\mathrm{R}^{2}$ ve hata varyans değerleri, ölçeğin uyumlu olduğunu göstermektedir.

\subsubsection{Müşterilerle Çevresel İşbirliği Ölçeğinin Testi}

Araştırmada kullanılan yeşil tedarik zinciri boyutlarından müşterilerle çevresel işbirliği ölçeğini oluşturan boyutlar ayrı ayrı doğrulayıcı faktör analizine tabi tutulmuştur. Doğrulayıcı faktör analizi sonucu uyum değerleri kabul edilebilir sınırlar içerisinde olduğu için modifikasyon yapılmamıştır. Analiz sonucu elde edilen uyum değerleri Tablo 17' de gösterilmiştir.

Tablo 17. Müşterilerle Çevresel İşbirliği Ölçeğinin Uyum Değerleri

\begin{tabular}{|l|c|c|c|}
\hline \multicolumn{1}{|c|}{ Uyumluluk İndeksi } & Değerler & Uyumluluk İndeksi & Değerler \\
\hline Ki-Kare $\left(\mathrm{X}^{2}\right)$ & 7.70 & CFI & 0.99 \\
\hline Serbestlik Derecesi & 5 & NNFI & 0.98 \\
\hline Ki-Kare/sd & 1.54 & NFI & 0.97 \\
\hline GFI & 0.97 & RMSR & 0.030 \\
\hline AGFI & 0.91 & RMSEA & 0.073 \\
\hline
\end{tabular}

Sonuçlara göre Ki-Kare/sd 1.54 ve ortalama hata karekökü (RMSEA) 0.073 olup kabul edilebilir sınırlar içerisindedir. Düzeltilmiş uyum indeksi (AGFI) değeri 0.91 ve karşılaştırmalı uyum indeksi (CFI) değeri 0.99 olup iyi düzeydedirler. Yeşil tedarik zinciri boyutlarından müşterilerle çevresel işbirliği ile ilgili yapılan doğrulayıcı faktör analizi sonucu elde edilen değerler Tablo 17 de gösterilirken ölçeğin boyutlarını 
oluşturan değişkenlerin standart değerleri, hata varyansları ve t değerleri Tablo $18^{\prime}$ de gösterilmiştir.

Tablo 18. Müşterilerle Çevresel işbirliği Ölçek Testi Sonrası Kalan Değişkenler

\begin{tabular}{|l|c|c|c|c|}
\hline \multicolumn{1}{|c|}{ Değişkenler } & S.Değer & $\mathbf{R}^{2}$ & H.Varyansi & t Değeri \\
\hline Çevresel hedefleri ortaklaşa başarmak-E21 & 0.67 & 0.45 & 0.50 & 6.90 \\
\hline Çevresel performansla ilgili sorumlulukların & 0.69 & 0.48 & 0.34 & 7.17 \\
\hline $\begin{array}{l}\text { Faaliyetlerimizin çevresel etkilerini azaltmak için } \\
\text { birlikte çalışmak-E23 }\end{array}$ & 0.66 & 0.44 & 0.52 & 6.77 \\
\hline $\begin{array}{l}\text { Çevreyle ilgili problemleri tahmin etmek ve } \\
\text { çözmek konusunda müşterek planlama } \\
\text { yürütmek-E24 }\end{array}$ & 0.65 & 0.42 & 0.44 & 6.65 \\
\hline $\begin{array}{l}\text { Ürünlerimizin çevreye olan etkisini azaltmak } \\
\text { konusunda müşterek kararlar vermek-E25 }\end{array}$ & 0.73 & 0.54 & 0.44 & 7.73 \\
\hline
\end{tabular}

Değerlere incelendiğinde standart değerlerin $0.98^{\prime}$ den küçük, $t$ değerlerinin ise 2'den büyük olması yine $\mathrm{R}^{2}$ ve hata varyans değerleri, ölçeğin uyumlu olduğunu göstermektedir.

\subsubsection{Müşterilerle Çevresel Yönetim Ölçeğinin Testi}

Yeşil tedarik zinciri boyutlarından müşteriler ile çevresel yönetim ölçeğini test etmek amacıyla, doğrulayıcı faktör analizi yapılmıştır. Doğrulayıcı faktör analizi sonucu uyum değerleri kabul edilebilir sınırlar içerisinde olduğu için modifikasyon yapılmamıştır. Analiz sonucu elde edilen uyum değerleri Tablo 19' da gösterilmiştir.

Tablo 19. Müşterilerle Çevresel Yönetim Ölçeğinin Uyum Değerleri

\begin{tabular}{|l|c|c|c|c|c|}
\hline Uyumluluk İndeksi & Değerler & $\begin{array}{c}\text { Uyumluluk } \\
\text { İndeksi }\end{array}$ & Değerler & U. İndeksi & Değerler \\
\hline Ki-Kare $\left(\mathrm{X}^{2}\right)$ & 7.62 & CFI & 0.99 & GFI & 0.97 \\
\hline Serbestlik Derecesi & 5 & NNFI & 0.98 & AGFI & 0.91 \\
\hline Ki-Kare/sd & 1.52 & NFI & 0.96 & RMSEA & 0.072 \\
\hline & & & & RMSR & 0.036 \\
\hline
\end{tabular}

Sonuçlara göre, Düzeltilmiş uyum endeksi(AGFI), değeri 0.91, Uyum iyiliği indeksi (GFI) 0.97, Karşılaştırmalı uyum indeksi(CFI) 0.99 ve Normlaştırılmamış uyum indeksi (NNFI) 0.98, olup kabul edilebilirlikleri iyi düzeydedir. Ortalama hata karekök yaklaşımı (RMSEA) 0.072 olup kabul edilebilir düzeydedir. Müşterilerle Çevresel Yönetim ile ilgili yapılan doğrulayıcı faktör analizi sonucu kalan değişkenler ve değerleri Tablo 20'de gösterilmiştir. 
Tablo 20. Müşterilerle Çevresel Yönetim Ölçek Testi Sonrası Kalan Değişkenleri

\begin{tabular}{|l|c|c|c|c|}
\hline \multicolumn{1}{|c|}{ Değişkenler } & S.Değer & $\mathbf{R}^{\mathbf{2}}$ & H.Varyansi & t Değeri \\
\hline $\begin{array}{l}\text { Kendi tedarikçilerini seçme konusunda çevresel } \\
\text { etmenleri dikkate alırlar-E31 }\end{array}$ & 0.57 & 0.32 & 0.68 & 5.68 \\
\hline $\begin{array}{l}\text { Bizim çevresel uygunluğumuzdan emin olmak } \\
\text { için bilgi talep ederler-E32 }\end{array}$ & 0.63 & 0.40 & 0.60 & 6.51 \\
\hline $\begin{array}{l}\text { Çevresel yönetim sistemini uyguladığımız için } \\
\text { bizi tercih ederler-E33 }\end{array}$ & 0.81 & 0.66 & 0.34 & 8.91 \\
\hline $\begin{array}{l}\text { Bizden atık azaltma hedeflerimizi yerine } \\
\text { getirmemizi isterler-E34 }\end{array}$ & 0.75 & 0.57 & 0.43 & 8.06 \\
\hline $\begin{array}{l}\text { Bize detaylı bir yazılı çevresel talepler listesi } \\
\text { sunarlarE35 }\end{array}$ & 0.59 & 0.35 & 0.65 & 5.96 \\
\hline
\end{tabular}

Değerlere incelendiğinde standart değerlerin 0.98 den küçük, $t$ değerlerinin ise 2 'den büyük olması yine $\mathrm{R}^{2}$ ve hata varyans değerleri, ölçeğin uyumlu olduğunu göstermektedir.

\subsubsection{1. İşletme Performansı Ölçeğinin Testi}

İşletme performansı ölçeğini test etmek amacıyla, doğrulayıcı faktör analizi yapılmıştır. Doğrulayıcı faktör analizi sonucu işletmelerin performans boyutu altında yer alan 16 değişkenin model uyum değerlerinin kabul edilebilir düzeyde olmadıkları görülmüştür. Analiz sonucunda önerilen modifikasyonlar yapılmış, modifikasyon öncesi ve sonrası model uyum değerleri Tablo 21'de gösterilmiştir

Tablo 21. İşletme performansı Ölçeğinin Uyum Değerleri

\begin{tabular}{|l|c|c|c|c|c|}
\hline Uyum İndeksi & Mod.Öncesi & Mod.Sonrasi & $\begin{array}{c}\text { Uyum } \\
\text { İndeksi }\end{array}$ & Mod.Öncesi & Mod. Sonrasi \\
\hline Ki-Kare & 253.18 & 47.69 & RMSR & 0.078 & 0.048 \\
\hline S.Derecesi & 101 & 32 & RMSEA & 0.122 & 0.070 \\
\hline Ki-Kare/sd & 2.506 & 1.49 & CFI & 0.91 & 0.98 \\
\hline GFI & 0.76 & 0.91 & NNFI & 0.90 & 0.97 \\
\hline AGFI & 0.68 & 0.85 & NFI & 0.87 & 0.95 \\
\hline
\end{tabular}

Doğrulayıcı faktör analizi sonuçlarına göre, 16 değişkenin yer aldığı işletme performansına ait model uyum değerlerinden Uyum iyiliği indeksi (GFI) 0.76, Düzeltilmiş uyum İndeksi (AGFI) 0.68, Karşılaştırmalı uyum indeksi (CFI) 0.91, Normlaştırılmamış uyum indeksi (NNFI) 0.90, uyumluluk için kabul edilebilir düzeyde değildir. $\mathrm{Bu}$ nedenle, analiz sonucu önerilen modifikasyonlar yapılmış, istatistiki bakımdan uygun olmayan $6(\mathrm{O} 4, \mathrm{O} 5, \mathrm{O} 7, \mathrm{O} 9, \mathrm{O} 12, \mathrm{O} 14)$ değişken elenmiştir. Sonuçlara göre, 47.69 ki kare değeri ve 32 serbestlik derecesinin birbirine oranı 1.49 
olup, 5'in altında olması nedeniyle istatistiki bakımdan kabul edilebilir bir değere sahiptir. Uyum iyiliği indeksi (GFI) 0.91 ve Düzeltilmiş uyum İndeksi (AGFI) 0.85 olup kabul edilebilir seviyededirler. Karşılaştırmalı uyum indeksi (CFI) 0.98 ve Normlaştırılmamış uyum indeksi (NNFI) 0.97 ise istatistiki bakımdan iyi düzeydedir. $\mathrm{Bu}$ değerlere göre işletme performansı altında yer alan değişkenlerin kabul edilebilirliği iyi düzeydedir. İşletme performansı ile ilgili yapılan doğrulayıcı faktör analizi sonucu kalan değişkenlerin değerleri Tablo 22' de gösterilmiştir.

Tablo 22. İşletme Performansı Ölçek Testi Sonrası Kalan Değişkenleri

\begin{tabular}{|l|c|c|c|c|}
\hline \multicolumn{1}{|c|}{ Değişkenler } & S.Değer & $\mathbf{R}^{2}$ & H.Varyansi & t Değeri \\
\hline ÇEVRESEL PERFORMANS & & & & \\
\hline Hava emisyonunun azaltımı-O1 & 0.64 & 0.41 & 0.53 & 6.27 \\
\hline Su emisyonunun azaltımı-O2 & 0.68 & 0.46 & 0.35 & 5.60 \\
\hline Katı atıkların azaltımı-O3 & 0.68 & .46 & 0.49 & 5.61 \\
\hline İ̧̧letmenin çevresel durumunu geliştirme-O6 & 0.74 & 0.55 & 0.38 & 6.00 \\
\hline EKONOMİK PERFORMANS & & & & \\
\hline Enerji tüketimi için maliyetleri düşürme-O8 & 0.73 & 0.54 & 0.44 & 5.51 \\
\hline Atık boşaltımı için ücretleri düşürme-O10 & 0.73 & 0.53 & 0.54 & 6.61 \\
\hline Çevresel kazalar için cezaların düşmesi-O11 & 0.69 & 0.48 & 0.50 & 6.33 \\
\hline İŞLEMSEL PERFORMANS & & & & \\
\hline Stok seviyesinin düşmesi-O13 & 0.78 & 0.61 & 0.40 & 4.53 \\
\hline $\begin{array}{l}\text { Ürün hattını artırmak-O15 } \\
\text { Kapasite kullanımını iyileştirmek16 }\end{array}$ & 0.69 & 0.48 & 0.38 & 6.28 \\
\hline
\end{tabular}

Değerler incelendiğinde zaman standart değerlerin 0.98' den küçük, $t$ değerlerinin ise 2 'den büyük olması yine $\mathrm{R}^{2}$ ve hata varyans değerleri, ölçeğin uyumlu olduğunu göstermektedir.

\subsubsection{Teknolojik ve Lojistik Bütünleşme Ölçeğinin Testi}

Teknolojik ve Lojistik Bütünleşme ölçeğini test etmek amacıyla, doğrulayıcı faktör analizi yapılmıştır. Doğrulayıcı faktör analizi sonucu Teknolojik ve Lojistik Bütünleşme boyutu altında yer alan 12 değişkenin model uyum değerlerinin kabul edilebilir düzeyde olmadıkları görülmüştür. Analiz sonucunda önerilen modifikasyonlar yapılmış, modifikasyon öncesi ve sonrası model uyum değerleri Tablo 23'de gösterilmiştir. 
Tablo 23. Teknolojik ve Lojistik Bütünleşme Ölçeğinin Uyum Değerleri

\begin{tabular}{|l|c|c|c|c|c|}
\hline \multicolumn{1}{|c|}{ Uyum İndeksi } & Mod.Öncesi & Mod.Sonrasi & Uyum İndeksi & Mod.Öncesi & Mod. Sonrasi \\
\hline Ki-Kare $\left(\mathrm{X}^{2}\right)$ & 129.03 & 24.97 & RMSR & 0.066 & 0.038 \\
\hline S.Derecesi & 53 & 26 & RMSEA & 0.119 & 0.00 \\
\hline Ki-Kare/sd & 2.434 & 0.96 & CFI & 0.93 & 1.00 \\
\hline GFI & 0.82 & 0.95 & NNFI & 0.91 & 1.00 \\
\hline AGFI & 0.74 & 0.91 & NFI & 0.90 & 0.96 \\
\hline
\end{tabular}

Doğrulayıcı faktör analizi sonuçlarına göre, 12 değişkenin yer aldığ teknolojik ve lojistik bütünleşmeye ait model uyum değerlerinden Uyum iyiliği indeksi (GFI) 0.82, Düzeltilmiş uyum İndeksi (AGFI) 0.74, Karşılaştırmalı uyum indeksi (CFI) 0.93, Normlaştırılmamış uyum indeksi (NNFI) 0.91 değerleri kabul edilebilir düzeyde değildir. $\mathrm{Bu}$ nedenle, analiz sonucu önerilen modifikasyonlar yapılmış, istatistiki bakımdan uygun olmayan 3 (İ5, B5, B7) değişken elenmiştir.

Sonuçlara göre, Uyum iyiliği indeksi (GFI) 0.95 ve Düzeltilmiş uyum İndeksi (AGFI) 0.91. Karşılaştırmalı uyum indeksi (CFI) 1.00 ve Normlaştırılmamış uyum indeksi (NNFI) 1.00 ise istatistiki bakımdan iyi düzeydedirler. Normlaştırılmış uyum indeksi(NFI) ise 0.96 değere sahip olup kabul edilebilir seviyededir. Bu değerlere göre teknolojik ve lojistik bütünleşme altında yer alan değişkenlerin kabul edilebilirliği iyi düzeydedir. Teknolojik ve lojistik bütünleşme ile ilgili yapılan doğrulayıcı faktör analizi sonucu kalan değişskenlerin değerleri Tablo 24'de gösterilmiştir.

Tablo 24. Teknolojik ve Lojistik Bütünleşme Ölçek Testi Sonrası Kalan Değişkenleri

\begin{tabular}{|l|c|c|c|c|}
\hline \multicolumn{1}{|c|}{ Değişkenler } & S.Değer & $\mathbf{R}^{2}$ & H.Varyans & t Değeri \\
\hline $\begin{array}{l}\text { Birincil tedarikçilerimizin ilerlemesine yardım edecek } \\
\text { bilgileri sağlar -İ1 }\end{array}$ & 0.71 & 0.50 & 0.45 & 7.43 \\
\hline $\begin{array}{l}\text { Birincil tedarikçileriyle işlemsel ve lojistikle ilgili bilgi } \\
\text { alış verişinde bulunur-I2 }\end{array}$ & 0.74 & 0.54 & 0.30 & 7.77 \\
\hline $\begin{array}{l}\text { Önceden belirlenmiş bir anlaşma olmadan birincil } \\
\text { tedarikçileriyle gayri resmi olarak bilgi alış verişinde } \\
\text { bulunur-i3 }\end{array}$ & 0.67 & 0.45 & 0.50 & 6.96 \\
\hline $\begin{array}{l}\text { Birincil tedarikçilerimizi etkileyebilecek olan olay ve } \\
\text { değişiklikleri onlara bildirir-i4 }\end{array}$ & 0.54 & 0.29 & 0.54 & 5.33 \\
\hline $\begin{array}{l}\text { Performansımızın artmasına yardım etmek için } \\
\text { tesislerimizi ziyaret ederler-B1 }\end{array}$ & 0.81 & 0.65 & 0.30 & 9.38 \\
\hline $\begin{array}{l}\text { Tatmin olmuş bir müşteri olmamız için kendi } \\
\text { çalışanlarını ve kaynaklarını tahsis ederler-B2 }\end{array}$ & 0.82 & 0.68 & 0.22 & 9.60 \\
\hline
\end{tabular}


Tablo 24. Teknolojik ve Lojistik Bütünleşme Ölçek Testi Sonrası Kalan Değişkenleri (Devami)

\begin{tabular}{|l|c|c|c|c|}
\hline \multicolumn{1}{|c|}{ Değişkenler } & S.Değer & $\mathbf{R}^{\mathbf{2}}$ & H.Varyans & t Değeri \\
\hline $\begin{array}{l}\text { Bize sadece ürünlerini değil, aynı zamanda } \\
\text { yeteneklerini de satarlar-B3 }\end{array}$ & 0.76 & 0.57 & 0.40 & 8.52 \\
\hline Sattıkları ürünleri hakkında eğitim verirler-B4 & 0.58 & 0.33 & 0.63 & 6.01 \\
\hline $\begin{array}{l}\text { Onlardan sipariş ettiğimiz ürünlerin kalitesini } \\
\text { geliştirmek için bizimle beraber gayret gösterirler-B6 }\end{array}$ & 0.64 & .41 & 0.57 & 6.82 \\
\hline
\end{tabular}

Değerler incelendiğinde zaman standart değerlerin $0.98^{\prime}$ den küçük, t değerlerinin ise 2 'den büyük olması yine $\mathrm{R}^{2}$ ve hata varyans değerleri, ölçeğin uyumlu olduğunu göstermektedir.

\subsubsection{Müşteri Kaynak ve Müşteri Lojistik Bütünleşme Ölçeğinin Testi}

Müşteri kaynak ve müşteri lojistik bütünleşme ölçeğini test etmek amacıyla, doğrulayıcı faktör analizi yapılmıştır. Doğrulayıcı faktör analizi sonucu müşteri kaynak ve müşteri lojistik bütünleşme boyutu altında yer alan 12 değişkenin model uyum değerlerinin kabul edilebilir düzeyde olmadıkları görülmüştür. Analiz sonucunda önerilen modifikasyonlar yapılmış, modifikasyon öncesi ve sonrası model uyum değerleri Tablo 25' de gösterilmiştir.

Tablo 25. Müşteri Kaynak ve Müşteri Lojistik Bütünleşme Ölçeğinin Uyum Değerleri

\begin{tabular}{|l|c|c|c|c|c|}
\hline \multicolumn{1}{|c|}{ Uyum İndeksi } & Mod.Öncesi & Mod.Sonrası & Uyum İndeksi & Mod.Öncesi & Mod. Sonrasi \\
\hline Ki-Kare $\left(X^{2}\right)$ & 138.41 & 24.97 & RMSR & 0.069 & 0.038 \\
\hline Serb.Derecesi & 53 & 26 & RMSEA & 0.126 & 0.00 \\
\hline Ki-Kare/sd & 2.611 & 0.96 & CFI & 0.93 & 1.00 \\
\hline GFI & 0.81 & 0.95 & NNFI & 0.91 & 1.00 \\
\hline AGFI & 0.73 & 0.91 & NFI & 0.89 & 0.96 \\
\hline
\end{tabular}

Doğrulayıcı faktör analizi sonuçlarına göre, 12 değişkenin yer aldığı müşteri kaynak ve müşteri lojistik bütünleşmesine ait model uyum değerlerinden Uyum iyiliği indeksi (GFI) 0.81, Düzeltilmiş uyum İndeksi (AGFI) 0.73, Karşılaştırmalı uyum indeksi (CFI) 0.93, Normlaştırılmamış uyum indeksi (NNFI) 0.89 değerleri kabul edilebilir düzeyde değildir. $\mathrm{Bu}$ nedenle, analiz sonucu önerilen modifikasyonlar yapılmış, istatistiki bakımdan uygun olmayan 3(B21, B26, B28) değişken elenmiştir. Sonuçlara göre, Uyum iyiliği indeksi (GFI) 0.95 ve Düzeltilmiş uyum İndeksi (AGFI) 0.91. Karşılaştırmalı uyum indeksi (CFI) 1.00 ve Normlaştırılmamış uyum indeksi (NNFI)1.00 ise istatistiki bakımdan iyi düzeydedirler. Normlaştırılmış uyum indeksi(NFI) ise 0.96 değere sahip olup kabul edilebilir seviyededir. 
$\mathrm{Bu}$ değerlere göre müşteri kaynak ve müşteri lojistik bütünleşmesi altında yer alan değişkenlerin kabul edilebilirliği iyi düzeydedir. Müşteri kaynak ve müşteri lojistik bütünleşmesi ile ilgili yapılan doğrulayıcı faktör analizi sonucu kalan değişkenlerin değerleri Tablo 26'da gösterilmiştir.

Tablo 26. Müşteri Kaynak ve Müşteri Lojistik Bütünleşme Ölçek Testi Sonrası Kalan Değişkenleri

\begin{tabular}{|l|c|c|c|c|}
\hline \multicolumn{1}{|c|}{ Değişkenler } & S.Değer & $\mathbf{R}^{2}$ & H.Varyansi & T Değeri \\
\hline Personelimize eğitim imkanı sağlarlar- B11 & 0.71 & 0.50 & 0.45 & 7.43 \\
\hline $\begin{array}{l}\text { Performansımızın artmasına yardım etmek için } \\
\text { tesislerimizi ziyaret ederler-B12 }\end{array}$ & 0.74 & 0.54 & 0.30 & 7.77 \\
\hline $\begin{array}{l}\text { Ürünlerimizin nasıl kullanıldı̆̆ını göstermek için } \\
\text { bizi tesislerine davet ederler-B13 }\end{array}$ & 0.67 & 0.45 & 0.50 & 6.96 \\
\hline $\begin{array}{l}\text { Basım sürecine katılırlar ve basımın ilk } \\
\text { aşamalarında bize yardımcı olurlar-B14 }\end{array}$ & 0.54 & 0.29 & 0.54 & 5.33 \\
\hline $\begin{array}{l}\text { Isşlemlerimize yardımcı olabilecek bilgileri } \\
\text { sağlarlar-B22 }\end{array}$ & 0.81 & 0.65 & 0.30 & 9.38 \\
\hline $\begin{array}{l}\text { Mevcut ambalajlamadaki önemli dizayn } \\
\text { değişiklikleriyle ilgili üretim konularını bizimle } \\
\text { müzakere ederler-B23 }\end{array}$ & 0.82 & 0.68 & 0.22 & 9.60 \\
\hline $\begin{array}{l}\text { Bizimle özel bir anlaşma olmadan gayri resmi } \\
\text { olarak bilgi alıs verișinde bulunur-B24 }\end{array}$ & 0.76 & 0.57 & 0.40 & 8.52 \\
\hline $\begin{array}{l}\text { Bizimle planlama yapma amacı ile yüz yüze } \\
\text { iletişimde bulunurlar-B25 }\end{array}$ & 0.58 & 0.33 & 0.63 & 6.01 \\
\hline $\begin{array}{l}\text { Ürün sevkiyatı ile ilgili isteklerde esnekliğe izin } \\
\text { verirler- B27 }\end{array}$ & 0.64 & 0.41 & 0.57 & 6.82 \\
\hline
\end{tabular}

Değerler incelendiğinde standart değerlerin $0.98^{\prime}$ den küçük, $t$ değerlerinin ise $2^{\prime}$ den büyük olması yine $\mathrm{R}^{2}$ ve hata varyans değerleri, ölçeğin uyumlu olduğunu göstermektedir.

\subsubsection{Tedarikçilerle Yeşil Tedarik Zinciri Uygulamaları Ölçeğinin Testi}

Tedarikçilerle yeşil tedarik zinciri uygulamaları ölçeğini test etmek amacıyla, doğrulayıcı faktör analizi yapılmıştır. Doğrulayıcı faktör analizi sonucu tedarikçilerle yeşil tedarik zinciri boyutu altında yer alan değişkenlerin model uyum değerlerinin kabul edilebilir düzeyde olmadıkları görülmüştür. Analiz sonucunda önerilen modifikasyonlar yapılmış, modifikasyon öncesi ve sonrası model uyum değerleri Tablo 27' de gösterilmiştir. 
Tablo 27. Tedarikçilerle Yeşil Tedarik Zinciri Uygulamaları Ölçeğinin Uyum Değerleri

\begin{tabular}{|l|c|c|c|c|c|}
\hline \multicolumn{1}{|c|}{ Uyum İndeksi } & Mod.Öncesi & Mod.Sonrasi & $\begin{array}{c}\text { Uyum } \\
\text { İndeksi }\end{array}$ & Mod.Öncesi & Mod. Sonrasi \\
\hline Ki-Kare $\left(\mathrm{X}^{2}\right)$ & 464.35 & 34.52 & AGFI & 0.60 & 0.87 \\
\hline Ser.Derecesi & 167 & 24 & RMSR & 0.086 & 0.066 \\
\hline Ki-Kare/sd & 2.78 & 1.43 & RMSEA & 0.133 & 0.045 \\
\hline GFI & 0.69 & 0.93 & CFI & 0.89 & 0.98 \\
\hline NFI & 0.85 & 0.95 & NNFI & 0.88 & 0.97 \\
\hline
\end{tabular}

Doğrulayıcı faktör analizi sonuçlarına göre, 20 değişkenin yer aldığ tedarikçilerle yeşil tedarik zinciri uygulamalarına ait model uyum değerlerinden Uyum iyiliği indeksi (GFI) 0.69,Karşılaştırmalı uyum indeksi (CFI) 0.89, Normlaştırılmamış uyum indeksi (NNFI) 0.88 değerleri kabul edilebilir düzeyde değildir. Bu nedenle, analiz sonucu önerilen modifikasyonlar yapılmış, istatistiki bakımdan uygun olmayan 11 (D12, D13, D14, D15, D17, D110, D22, D24, D25, D31, D34) değişken elenmiştir. Sonuçlara göre, Uyum iyiliği indeksi (GFI) 0.93 ve Normlaştırılmış uyum indeksi (NFI) ise 0.95 kabul edilebilir düzeydedir. Normlaştırılmamış uyum indeksi (NNFI) 0.97 ise Karşılaştırmalı uyum indeksi (CFI) 0.98 istatistiki bakımdan iyi düzeydedir.

$\mathrm{Bu}$ değerlere göre, tedarikçilerle yeşil tedarik zinciri uygulamaları altında yer alan değişkenlerin kabul edilebilirliği iyi düzeydedir. Tedarikçilerle yeşil tedarik zinciri uygulamaları ile ilgili yapılan doğrulayıcı faktör analizi sonucu kalan değişkenlerin değerleri Tablo $28^{\prime}$ de gösterilmiştir.

Tablo 28. Tedarikçilerle Yeşil Tedarik Zinciri Uygulamaları Ölçeğinin Ölçek Testi Sonrası Kalan Değişkenleri

\begin{tabular}{|l|l|l|l|l|}
\hline \multicolumn{1}{|c|}{ Değişkenler } & S.Değer & $\mathbf{R}^{2}$ & H.Varyans1 & t Değeri \\
\hline $\begin{array}{l}\text { Çevre yönetimi ve teknolojilerindeki bilgi ve } \\
\text { uzmanlıklarını paylaşırlar- D11 }\end{array}$ & 0.55 & 0.31 & 0.62 & 6.60 \\
\hline $\begin{array}{l}\text { Çevresel ambalajlama uygulamalarında işbirliği } \\
\text { yaparlar- D16 }\end{array}$ & 0.70 & 0.62 & 0.33 & 5.37 \\
\hline $\begin{array}{l}\text { Ürün dizaynın da üretim sürecinde ki tehlikeli } \\
\text { ürünlerin kullanımını azaltmak için işbirliği } \\
\text { yaparlar-D18 }\end{array}$ & 0.73 & 0.53 & 0.44 & 5.17 \\
\hline $\begin{array}{l}\text { Ürün dizaynın da enerji tüketimini azaltmak için } \\
\text { işbirliği yaparlar-D19 }\end{array}$ & 0.65 & 0.43 & 0.54 & 4.85 \\
\hline \begin{tabular}{l} 
Çevresel hedefleri ortaklaşa başarmak-D21 \\
\hline
\end{tabular} & 0.59 & 0.34 & 0.64 & 5.85 \\
\hline
\end{tabular}


Tablo 28. Tedarikçilerle Yeşil Tedarik Zinciri Uygulamaları Ölçeğinin Ölçek Testi Sonrası Kalan Değişkenleri (Devamı)

\begin{tabular}{|l|l|l|l|l|}
\hline \multicolumn{1}{|c|}{ Değişkenler } & S.Değer & $\mathbf{R}^{2}$ & H.Varyansi & t Değeri \\
\hline $\begin{array}{l}\text { Faaliyetlerimizin çevreye olan etkisini azaltmak } \\
\text { için birlikte çalışmak-D23 }\end{array}$ & 0.57 & 0.33 & 0.70 & 5.37 \\
\hline $\begin{array}{l}\text { Tedarikçilere yazılı çevresel istekleri bildirmek - } \\
\text { D32 }\end{array}$ & 0.69 & 0.47 & 0.52 & 5.87 \\
\hline $\begin{array}{l}\text { Tedarikçilere uygunluklarını gözlemlemek için } \\
\text { çevreyle ilgili anketler yollamak-D33 }\end{array}$ & 0.68 & 0.47 & 0.49 & 6.03 \\
\hline $\begin{array}{l}\text { Tedarikçilerin atık azaltma hedeflerine sahip } \\
\text { olmalarını istemek-D35 }\end{array}$ & 0.64 & 0.86 & 0.38 & 5.72 \\
\hline
\end{tabular}

Değerler incelendiğinde standart değerlerin $0.98^{\prime}$ den küçük, $t$ değerlerinin ise 2 'den büyük olması yine $\mathrm{R}^{2}$ ve hata varyans değerleri, ölçeğin uyumlu olduğunu göstermektedir. Ölçeklerdeki değişkenlerin toplamları alınarak yapılan analizler sonucu ölçekler doğrulanmış ve uyumlar kabul edilebilir görülmüştür. Ölçekler ve doğrulayıcı faktör analizleri sonuçları aşağıda belirtilmiştir.

\subsection{Doğrulayıcı Faktör Analizi Sonuçları}

\subsubsection{Tedarik Zincirinde Bütünleşme Ölçeğinin Doğrulayıcı Faktör Analizi}

Müşteri ve tedarikçilerle bütünleşme ölçeğinin altındaki değişkenlerin toplamları alınarak analizleri yapılmış, ölçekler doğrulanmış ve uyum kabul edilebilir görülmüştür. Sonuçlar Tablo 29' da gösterilmiştir.

Tablo 29. Müşteri ve Tedarikçilerle Bütünleşme Doğrulayıcı Faktör Analizi Sonuçları

\begin{tabular}{|l|c|c|c|c|c|}
\hline Uyum İndeksi & Mod.Öncesi & Mod.Sonrasi & $\begin{array}{c}\text { Uyum } \\
\text { İndeksi }\end{array}$ & Mod.Öncesi & Mod. Sonrası \\
\hline Ki-Kare $\left(\mathrm{X}^{2}\right)$ & 0.06 & RMSR & 0.003 & GFI & 1.00 \\
\hline S.Derecesi & 1 & RMSEA & 0.00 & AGFI & 1.00 \\
\hline Ki-Kare/sd & 0.06 & CFI & 1.00 & NNFI & 1.00 \\
\hline & & & & NFI & 1.00 \\
\hline
\end{tabular}

Müşteri ve tedarikçilerle bütünleşme ölçeğinin toplamları alınarak yapılan doğrulayıcı faktör analizi sonucu kalan değişkenlerin değerleri Tablo 30'da gösterilmiştir. 
Tablo 30. Müşteri ve Tedarikçilerle Bütünleşme Ölçeğinin Toplamları Alınarak Yapılan Doğrulayıcı Faktör Analizi Sonucu Kalan Değerleri

\begin{tabular}{|l|c|c|c|c|}
\hline \multicolumn{1}{|c|}{ Değişkenler } & S.Değer & $\mathbf{R}^{2}$ & H.varyans1 & T.Değeri \\
\hline Lojistik bütünleşme- tedarikçi bütünleşmesi & 0.71 & 0.50 & 0.45 & 6.93 \\
\hline $\begin{array}{l}\text { Teknolojik bütünleşme- tedarikçi bütünleşmesi } \\
\text { Müşteri kaynak bütünleşmesi- müşteri } \\
\text { bütünleşmesi }\end{array}$ & 0.68 & 0.47 & 0.49 & 6.14 \\
\hline $\begin{array}{l}\text { Müşterilerle lojistik bütünleşme-müşteri } \\
\text { bütünleşmesi }\end{array}$ & 0.59 & 0.35 & 0.49 & 5.47 \\
\hline
\end{tabular}

Müşteri ve tedarikçilerle bütünleşme ölçeğinde yer alan boyutların standart ve $\mathrm{t}$ değerleri sırasıyla; Lojistik bütünleşme ve tedarikçi bütünleşmesi (0.71), (6.93), Teknolojik bütünleşme ve tedarikçi bütünleşmesi (0.76),(7.38), Müşteri kaynak bütünleşmesi ve müşteri bütünleşmesi (0.68), (6.14), Müşterilerle lojistik bütünleşme ve müşteri bütünleşmesi, (0.59), (5.47)'dir. Teknolojik bütünleşme, (0.58) tedarikçi bütünleşmesini lojistik bütünleşmeden (0.50) daha fazla etkilemektedir. Yine müşterilerle kaynak bütünleşmesi (0.47) müşteri bütünleşmesini lojistik bütünleşmeden daha fazla etkilemektedir. Bu durumda H1a, H1b, H2a, H2b hipotezleri kabul edilmiştir.

2.4.2.Tedarikçilerle Yeşil Tedarik Zinciri Uygulamalan Ölçeğinin Doğrulayıcı Faktör Analizi

Tedarikçilerle yeşil tedarik zinciri uygulamaları ölçeğinin altındaki değişkenlerin toplamları alınarak analizleri yapılmış, ölçekler doğrulanmış ve uyum kabul edilebilir görülmüştür. Sonuçlar Tablo 31'de gösterilmiştir.

Tablo 31. Tedarikçilerle Yeşil Tedarik Zinciri Uygulamaları Ölçeğinin Doğrulayıcı Faktör Analizi Sonuçları

\begin{tabular}{|l|c|c|c|c|c|}
\hline Uyum İndeksi & Mod.Öncesi & Mod.Sonrası & Uyum İndeksi & Mod.Öncesi & Mod. Sonrasi \\
\hline Ki-Kare $\left(\mathrm{X}^{2}\right)$ & 0.00 & Ki-Kare/sd & 0.00 & S. Derecesi & 0.00 \\
\hline
\end{tabular}

Tedarikçilerle yeşil tedarik zinciri uygulamaları ölçeğinin toplamları alınarak yapılan doğrulayıcı faktör analizi sonucu kalan değişkenlerin değerleri Tablo 32'de gösterilmiştir. 
Tablo 32. Tedarikçilerle yeşil tedarik zinciri uygulamaları ölçeğinin toplamları alınarak yapılan doğrulayıcı faktör analizi değişken ve değerleri

\begin{tabular}{|l|c|c|c|c|}
\hline \multicolumn{1}{|c|}{ Değişkenler } & S.Değer & $\mathbf{R}^{2}$ & H.varyansi & T Değeri \\
\hline $\begin{array}{l}\text { Tedarikçilerle çevresel yönetim- yeşil tedarik } \\
\text { zinciri uygulamaları }\end{array}$ & 0.70 & 0.49 & 0.46 & 6.52 \\
\hline $\begin{array}{l}\text { Tedarikçilerle çevresel hareket- yeşil tedarik } \\
\text { zinciri uygulamaları }\end{array}$ & 0.77 & 0.59 & 0.26 & 7.03 \\
\hline $\begin{array}{l}\text { Tedarikçilerle çevresel işbirliği-yeşil tedarik } \\
\text { zinciri uygulamaları }\end{array}$ & 0.62 & 0.39 & 0.56 & 5.88 \\
\hline
\end{tabular}

Tedarikçilerle yeşil tedarik zinciri uygulamaları ölçeğinde yer alan boyutların standart ve $\mathrm{t}$ değerleri sırasıyla; Tedarikçilerle çevresel yönetim (0.70), (6.52), Tedarikçilerle çevresel hareket (0.77), (7.03), Tedarikçilerle çevresel işbirliği (0.62), (5.88)'dir. Tedarikçilerle çevresel hareketler, (0.59) tedarikçilerle çevresel yönetim, (0.49) ve tedarikçilerle çevresel işbirliğinden (0.39) daha fazla yeşil tedarik zinciri uygulamalarını etkilemektedir. Bu durumda H6a, H6b, H6c hipotezleri kabul edilmektedir.

\section{Faktör Analizi}

\subsubsection{Müşterilerle Yeşil Tedarik Zinciri Uygulamaları Ölçeğinin Doğrulayıcı}

Müşterilerle Yeşil Tedarik Zinciri Uygulamaları ölçeğinin altındaki değişkenlerin toplamları alınarak analizleri yapılmış ve ölçekler doğrulanmış ve uyum kabul edilebilir görülmüş̧tür. Sonuçlar Tablo 33' de gösterilmiştir.

Tablo 33. Müşterilerle Yeşil Tedarik Zinciri Uygulamaları Ölçeğinin Doğrulayıcı

Faktör Analizi Sonuçları

\begin{tabular}{|l|c|c|c|c|c|}
\hline Uyum İndeksi & Mod.Öncesi & $\begin{array}{c}\text { Uyum } \\
\text { İndeksi }\end{array}$ & Mod.Öncesi & $\begin{array}{c}\text { Uyum } \\
\text { İndeksi }\end{array}$ & Mod.Öncesi \\
\hline Ki-Kare $\left(\mathrm{X}^{2}\right)$ & 0.00 & Ki-Kare/sd & 0.00 & S.Derecesi & 0.00 \\
\hline
\end{tabular}

Müşterilerle Yeşil Tedarik Zinciri Uygulamaları ölçeğinin toplamları alınarak yapılan doğrulayıcı faktör analizi sonucu kalan değişkenlerin değerleri Tablo 34'de gösterilmiştir. 
Tablo 34. Müşterilerle Yeşil Tedarik Zinciri Uygulamaları Ölçeğinin Toplamları Alınarak Yapılan Doğrulayıcı Faktör Analizi Değişken ve Değerleri

\begin{tabular}{|l|c|c|c|c|}
\hline \multicolumn{1}{|c|}{ Değişkenler } & S.Değer & $\mathbf{R}^{\mathbf{2}}$ & H.varyans1 & T Değeri \\
\hline $\begin{array}{l}\text { Müşterilerle çevresel yönetim- yeşil tedarik } \\
\text { zinciri uygulamaları }\end{array}$ & 0.70 & 0.49 & 0.46 & 6.52 \\
\hline $\begin{array}{l}\text { Müşterilerle çevresel hareket- yeşil tedarik zinciri } \\
\text { uygulamaları }\end{array}$ & 0.77 & 0.26 & 0.59 & 7.03 \\
\hline $\begin{array}{l}\text { Müşterilerle çevresel işbirliği- yeşil tedarik } \\
\text { zinciri uygulamaları }\end{array}$ & 0.62 & 0.56 & 0.39 & 5.88 \\
\hline
\end{tabular}

Müşterilerle Yeşil Tedarik Zinciri Uygulamaları ölçeğinde yer alan boyutların standart ve t değerleri sırasıyla; müşterilerle çevresel yönetim (0.70),(6.52), müşterilerle çevresel hareket (0.77), (7.03), müşterilerle çevresel işbirliği ve (0.62), (5.88)'dir. Müşterilerle çevresel işbirliği (0.56), müşterilerle çevresel yönetim(0.49) ve müşterilerle çevresel hareket(0.26) 'dır.Bu durumda H5a, H5bve H5c hipotezleri kabul edilmiştir.

\subsection{4.İşletme Performansı Ölçeğinin Doğrulayıcı Faktör Analizi}

İşletme performansı ölçeğinin altındaki değişkenlerin toplamları alınarak analizleri yapılmış ve ölçekler doğrulanmış ve uyum kabul edilebilir görülmüştür. Sonuçlar Tablo 35'de gösterilmiştir.

Tablo 35. İşletme Performansı Ölçeğinin Doğrulayıcı Faktör Analizi Sonuçları

\begin{tabular}{|l|c|c|c|c|c|}
\hline $\begin{array}{c}\text { Uyumluluk } \\
\text { İndeksi }\end{array}$ & $\begin{array}{c}\text { Modifikasyon } \\
\text { Öncesi }\end{array}$ & $\begin{array}{c}\text { Uyumluluk } \\
\text { İndeksi }\end{array}$ & $\begin{array}{c}\text { Modifikasyon } \\
\text { Öncesi }\end{array}$ & $\begin{array}{c}\text { Uyumluluk } \\
\text { İndeksi }\end{array}$ & $\begin{array}{c}\text { Modifikasyon } \\
\text { Öncesi }\end{array}$ \\
\hline Ki-Kare $\left(X^{2}\right)$ & 0.00 & Ki-Kare/sd & 0.00 & S.Derecesi & 0.00 \\
\hline RMSEA & 0.00 & & & & \\
\hline
\end{tabular}

İşletme performansı ölçeğinin toplamları alınarak yapılan doğrulayıcı faktör analizi sonucu kalan değişkenlerin değerleri Tablo 36'da gösterilmiştir.

Tablo 36. İşletme performansı ölçeğinin toplamları alınarak yapılan doğrulayıcı faktör analizi değişken ve değerleri

\begin{tabular}{|l|c|c|c|c|}
\hline \multicolumn{1}{|c|}{ Değişkenler } & S.değer & $\mathbf{r}^{2}$ & H.varyansı & Tdeğeri \\
\hline İşlemsel performans-işletme performansı & 0.70 & 0.49 & 0.46 & 6.52 \\
\hline Ekonomik performans-işleme performansı & 0.77 & 0.59 & 0.26 & 7.03 \\
\hline Çevresel performans-işletme performansı & 0.62 & 0.39 & 0.56 & 5.88 \\
\hline
\end{tabular}

İşletme performansı ölçeğinde yer alan boyutların standart ve $\mathrm{t}$ değerleri sırasıyla; işlemsel performans (0.70),(6.52), ekonomik performans (0.77), (7.03),çevresel performans (0.62), (5.88)'dir. Ekonomik performans, (0.59) işlemsel (0.49) ve çevresel 
performans (0.39) dan daha fazla işletme performansını etkilemektedir. Bu durumda H8,H9,H10 hipotezleri kabul edilmektedir.

\subsection{Araştırma Modelinin Path Analizi}

Araştırma modelinde yer alan ölçüm modelleri doğrulayıcı faktör analizine tabi tutulduktan sonra kalan değişkenler kullanılarak bütünleşme, yeşil tedarik zinciri uygulamaları ve performans arasındaki ilişkileri belirlemek amacıyla Path (yol) analizi yapılmıştır. Path analizinin ilk aşamasında uyum indeks değerlerinin kabul edilebilir sınırlar içerisinde olmadı ğ görülmüş̧tür. Araştırma modeline ait uyum değerlerinden Düzeltilmiş uyum İndeksi (AGFI), 0.77, Ortalama hataların karekökü (RMSR) 0.54, Normlaştırılmamış uyum indeksi (NNFI),0.91 ve Normlaştırılmış uyum indeksi (NFI)0.93 model uyumluluğu için kabul edilebilir düzeyde değildir. Bu nedenle analiz sonucu önerilen modifikasyonlar yapılmış 13 (E32, O1, O2, O3, O6, O8, O10, O11, O16, E17, E19, D32, D34)değişken elenmiştir. Uyum değerleri Tablo 37' de gösterilmiştir.

Tablo 37. Path Analizi Uyum Değerleri

\begin{tabular}{|l|c|c|c|c|c|}
\hline \multicolumn{1}{|c|}{$\begin{array}{c}\text { Uyum } \\
\text { Indeksi }\end{array}$} & Mod.Öncesi & Mod.Sonrası & $\begin{array}{c}\text { Uyum } \\
\text { Indeksi }\end{array}$ & Mod.Öncesi & Mod. Sonrası \\
\hline Ki-Kare & 38.20 & 17.76 & RMSR & 0.54 & 0.05 \\
\hline S.Derecesi & 12 & 12 & RMSEA & 0.147 & 0.08 \\
\hline Ki-Kare/sd & 3.18 & 1.48 & CFI & 0.95 & 0.98 \\
\hline GFI & 0.90 & 0.93 & NNFI & 0.91 & 0.97 \\
\hline AGFI & 0.77 & 0.85 & NFI & 0.93 & 0.95 \\
\hline
\end{tabular}

Sonuçlara göre, Düzeltilmiş uyum İndeksi (AGFI), 0.85, Ortalama hataların karekökü (RMSR) 0.5, ve Normlaştırılmış uyum indeksi(NFI) 0.95 kabul edilebilir düzeydedir. Normlaştırılmamış uyum indeksi (NNFI), 0.97 ve Karşılaştırmalı uyum indeksi (CFI) model uyumluluğu için iyi düzeydedir. Bu değerlere göre, araştırma modeli kabul edilebilir düzeydedir. Araştırma modelinin modifikasyon sonrası değişkenleri arasındaki standart değerler, hata varyansı, $t$ değerleri Tablo 38'de gösterilmiştir. 
Tablo 38. Araştırma Modeli Değişkenleri Arasındaki İlişkiler

\begin{tabular}{|l|c|c|c|c|}
\hline \multicolumn{1}{|c|}{ Değişkenler } & S.Değer & $\mathbf{R}^{2}$ & H.Varyansı & tDeğeri \\
\hline Çevresel performans- işletme performansı & 0.58 & 0.34 & 0.61 & 5.40 \\
\hline Ekonomik performans- işletme performansı & 0.60 & 0.36 & 0.49 & 3.96 \\
\hline İşlemsel performans- işletme performansı & 0.90 & 0.81 & 0.18 & 4.81 \\
\hline Tedarikçiler-yeşil tedarik zinciri uygulamaları & 0.85 & 0.72 & 0.24 & 3.52 \\
\hline Müşteri-yeşil tedarik zinciri uygulamaları & 0.80 & 0.64 & 0.25 & 4.21 \\
\hline Tedarikçi bütünleşmesi-tedarik zinciri & 0.72 & 0.52 & 0.43 & 5.89 \\
\hline Müşteri bütünleşmesi-tedarik zinciri & 0.75 & 0.56 & 0.29 & 6.06 \\
\hline Yeşil tedarik zinciri uygulamaları-tedarik zinciri & 0.78 & 0.60 & 0.40 & 5.41 \\
\hline İşletme performansı ve yeşil tedarik zinciri & 0.86 & 0.75 & 0.25 & 4.30 \\
\hline
\end{tabular}

Sonuçlara göre, boyutlar arasında ki standart değerler şöyledir; çevresel performans ve işletme performansı arasında 0.58, $\mathrm{t}$ değeri: 5.40 ekonomik performans ve işletme performansı $0.60, \mathrm{t}$ değeri: 3.96 işlemsel performans ve işletme performansı 0.90, $\mathrm{t}$ değeri:4.81 tedarikçiler ve yeşil tedarik zinciri uygulamaları 0.85, $\mathrm{t}$ değeri:3.52 müşteri ve yeşil tedarik zinciri uygulamaları 0.80, $\mathrm{t}$ değeri:4.21, tedarikçi bütünleşmesi ve tedarik zinciri bütünleşmesi 0.72, $\mathrm{t}$ değeri:5.89 müşteri bütünleşmesi ve tedarik zinciri bütünleşme $0.75, \mathrm{t}$ değeri:6.06 yeşil tedarik zinciri uygulamaları ve tedarik zinciri bütünleşmesi $0.78, \mathrm{t}$ değeri:5.41 işletme performansı ve yeşil tedarik zinciri uygulamaları 0.86, t değeri:4.30' dur. Sonuçlara göre, H3a, H3b, H4, H5a, H5b, H8, H9, H10, H11 hipotezleri kabul edilmiştir. Yapılan path analizine göre, model için önerilen modifikasyonlar yapılmış ve istatistiki bakımdan uygun olmayan değişkenler elendikten sonra kalan değişkenler ve değerleri Tablo 39' da gösterilmiştir.

Tablo 39. Araştırma Modelinin Path Analizi Sonrası Kalan Değişkenleri

\begin{tabular}{|c|c|c|c|c|c|c|}
\hline $\begin{array}{c}\text { İşletme } \\
\text { performans1 } \\
\text { (alpha=0.93) }\end{array}$ & $\begin{array}{c}\text { Müşterilerin } \\
\text { Çevresel } \\
\text { Hareketleri } \\
\text { (Alpha=0.96) }\end{array}$ & $\begin{array}{c}\text { Tedarikçilerle } \\
\text { teknolojik } \\
\text { bütünleşme } \\
\text { (alpha=0.88) }\end{array}$ & $\begin{array}{c}\text { Müşterilerle } \\
\text { kaynak } \\
\text { bütünleşmesi } \\
\text { (alpha=0.83) }\end{array}$ & $\begin{array}{c}\text { Müşterilerle } \\
\text { Çevresel } \\
\text { İşbirliği } \\
\text { (Alpha=0.88) }\end{array}$ & $\begin{array}{c}\text { Tedarikçilerin } \\
\text { Çevresel } \\
\text { Hareketleri } \\
\text { (Alpha=0.95) }\end{array}$ & $\begin{array}{c}\text { Tedarikçilerle } \\
\text { Çevresel } \\
\text { İşbirliği } \\
\text { (Alpha=0.91) }\end{array}$ \\
\hline $\begin{array}{l}\text { Çevresel } \\
\text { performans }\end{array}$ & $\begin{array}{l}\text { Müşterilerin } \\
\text { Çevresel } \\
\text { Hareketleri- } \\
\text { E11 }\end{array}$ & $\begin{array}{l}\text { Tedarikçilerle } \\
\text { Teknolojik } \\
\text { Bütünleşme- } \\
\text { B1 }\end{array}$ & $\begin{array}{l}\text { Müşterilerle } \\
\text { Kaynak } \\
\text { Bütünleşmesi- } \\
\text { B11 }\end{array}$ & $\begin{array}{l}\text { Müşterilerle } \\
\text { Çevresel } \\
\text { İşbirliği-E21 }\end{array}$ & $\begin{array}{l}\text { Tedarikçilerin } \\
\text { Çevresel } \\
\text { Hareketleri- } \\
\text { D11 }\end{array}$ & $\begin{array}{l}\text { Tedarikçilerle } \\
\text { Çevresel } \\
\text { İşbirliği-D21 }\end{array}$ \\
\hline $\begin{array}{l}\text { Hava } \\
\text { emisyonunun } \\
\text { azatlımı-O1 }\end{array}$ & $\begin{array}{l}\text { Müşterilerin } \\
\text { Çevresel } \\
\text { Hareketleri- } \\
\text { E13 }\end{array}$ & $\begin{array}{l}\text { Tedarikçilerle } \\
\text { Teknolojik } \\
\text { Bütünleşme- } \\
\text { B2 }\end{array}$ & $\begin{array}{l}\text { Müşterilerle } \\
\text { Kaynak } \\
\text { Bütünleşmesi- } \\
\text { B12 }\end{array}$ & $\begin{array}{l}\text { Müşterilerle } \\
\text { Çevresel } \\
\text { İşbirliği -E22 }\end{array}$ & $\begin{array}{l}\text { Tedarikçilerin } \\
\text { Çevresel } \\
\text { Hareketleri- } \\
\text { D13 }\end{array}$ & $\begin{array}{l}\text { Tedarikçilerle } \\
\text { Çevresel } \\
\text { İşbirliği-D23 }\end{array}$ \\
\hline
\end{tabular}


Tablo 39. Araştırma Modelinin Path Analizi Sonrası Kalan Değişkenleri (Devamı)

\begin{tabular}{|c|c|c|c|c|c|c|}
\hline $\begin{array}{c}\text { İşletme } \\
\text { performansı } \\
\text { (alpha=0.93) }\end{array}$ & $\begin{array}{l}\text { Müşterilerin } \\
\text { Çevresel } \\
\text { Hareketleri } \\
\text { (Alpha=0.96) }\end{array}$ & $\begin{array}{c}\text { Tedarikçilerle } \\
\text { teknolojik } \\
\text { bütünleşme } \\
\text { (alpha=0.88) }\end{array}$ & $\begin{array}{c}\text { Müşterilerle } \\
\text { kaynak } \\
\text { bütünleşmesi } \\
\text { (alpha=0.83) }\end{array}$ & $\begin{array}{c}\text { Müşterilerle } \\
\text { Çevresel } \\
\text { İşbirliği } \\
\text { (Alpha }=0.88)\end{array}$ & $\begin{array}{c}\text { Tedarikçilerin } \\
\text { Çevresel } \\
\text { Hareketleri } \\
\text { (Alpha=0.95) }\end{array}$ & $\begin{array}{c}\text { Tedarikçilerle } \\
\text { Çevresel } \\
\text { İşbirliği } \\
\text { (Alpha=0.91) }\end{array}$ \\
\hline $\begin{array}{l}\mathrm{Su} \\
\text { emisyonunun } \\
\text { azaltımı-O2 }\end{array}$ & $\begin{array}{l}\text { Müşterilerin } \\
\text { Çevresel } \\
\text { Hareketleri- } \\
\text { E16 }\end{array}$ & $\begin{array}{l}\text { Tedarikçilerle } \\
\text { Teknolojik } \\
\text { Bütünleşme- } \\
\text { B4 }\end{array}$ & $\begin{array}{l}\text { Müşterilerle } \\
\text { Kaynak } \\
\text { Bütünleşmesi- } \\
\text { B13 }\end{array}$ & $\begin{array}{l}\text { Müşterilerle } \\
\text { Çevresel } \\
\text { İşbirliği-E23 }\end{array}$ & $\begin{array}{l}\text { Tedarikçilerin } \\
\text { Çevresel } \\
\text { Hareketleri- } \\
\text { D16 }\end{array}$ & $\begin{array}{l}\text { Tedarikçilerle } \\
\text { Çevresel } \\
\text { İşbirliği-D24 }\end{array}$ \\
\hline $\begin{array}{l}\text { Katı atıkların } \\
\text { azaltımı-O3 }\end{array}$ & $\begin{array}{l}\text { Müşterilerin } \\
\text { Çevresel } \\
\text { Hareketleri- } \\
\text { E18 }\end{array}$ & $\begin{array}{l}\text { Tedarikçilerle } \\
\text { Teknolojik } \\
\text { Bütünleşme- } \\
\text { B6 }\end{array}$ & $\begin{array}{l}\text { Müşterilerle } \\
\text { Kaynak } \\
\text { Bütünleşmesi- } \\
\text { B14 }\end{array}$ & $\begin{array}{l}\text { Müşterilerle } \\
\text { Çevresel } \\
\text { İşbirliği-E24 }\end{array}$ & $\begin{array}{l}\text { Tedarikçilerin } \\
\text { Çevresel } \\
\text { Hareketleri- } \\
\text { D17 }\end{array}$ & $\begin{array}{l}\text { Tedarikçilerle } \\
\text { Çevresel } \\
\text { İşbirliğiD25 }\end{array}$ \\
\hline $\begin{array}{l}\text { İşletmenin } \\
\text { çevresel } \\
\text { durumunu } \\
\text { geliş̧irme-O6 }\end{array}$ & $\begin{array}{l}\text { Tedarikçilerle } \\
\text { lojistik } \\
\text { bütünleşme } \\
\text { (alpha=0.81) }\end{array}$ & $\begin{array}{l}\text { Müşterilerle } \\
\text { lojistik } \\
\text { bütünleşme } \\
\text { (alpha=0.86) }\end{array}$ & $\begin{array}{l}\text { Tedarikçileri } \\
\mathrm{n} \text { çevresel } \\
\text { yönetimi } \\
\text { (alpha=0.87) }\end{array}$ & $\begin{array}{l}\text { Müşterilerle } \\
\text { Çevresel } \\
\text { İşbirliği-E25 }\end{array}$ & $\begin{array}{l}\text { Tedarikçilerin } \\
\text { Çevresel } \\
\text { Hareketleri- } \\
\text { D18 }\end{array}$ & $\begin{array}{l}\text { Müşteilerle } \\
\text { Çevresel } \\
\text { Yönetim } \\
\text { (Alpha=0.80) }\end{array}$ \\
\hline $\begin{array}{l}\text { Ekonomik } \\
\text { Performans }\end{array}$ & $\begin{array}{l}\text { Tedarikçilerle } \\
\text { Lojistik } \\
\text { Bütünleşme-İ1 }\end{array}$ & $\begin{array}{l}\text { Müşterilerle } \\
\text { Lojistik } \\
\text { Bütünleşme- } \\
\text { B23 }\end{array}$ & $\begin{array}{l}\text { Tedarikçilerin } \\
\text { Çevresel } \\
\text { Yönetimi-D31 }\end{array}$ & & $\begin{array}{l}\text { Tedarikçilerin } \\
\text { Çevresel } \\
\text { Hareketleri- } \\
\text { D19 }\end{array}$ & $\begin{array}{l}\text { Müşterilerle } \\
\text { Çevresel } \\
\text { Yönetim-E31 }\end{array}$ \\
\hline $\begin{array}{l}\text { Enerji tüketimi } \\
\text { için maliyetleri } \\
\text { düşürme-O8 }\end{array}$ & $\begin{array}{l}\text { Tedarikçilerle } \\
\text { Lojistik } \\
\text { Bütünleşme-ì2 }\end{array}$ & $\begin{array}{l}\text { Müşterilerle } \\
\text { Lojistik } \\
\text { Bütünleşme- } \\
\text { B24 }\end{array}$ & $\begin{array}{l}\text { Tedarikçilerin } \\
\text { Çevresel } \\
\text { Yönetimi-D32 }\end{array}$ & & & $\begin{array}{l}\text { Müşterilerle } \\
\text { Çevresel } \\
\text { Yönetim-e32 }\end{array}$ \\
\hline $\begin{array}{l}\text { Atık boşaltımı } \\
\text { için ücretleri } \\
\text { düşürme-O10 }\end{array}$ & $\begin{array}{l}\text { Tedarikçilerle } \\
\text { Lojistik } \\
\text { Bütünleşme-İ3 }\end{array}$ & $\begin{array}{l}\text { Müşterilerle } \\
\text { Lojistik } \\
\text { Bütünleşme- } \\
\text { B25 }\end{array}$ & $\begin{array}{l}\text { Tedarikçilerin } \\
\text { Çevresel } \\
\text { Yönetimi-D33 }\end{array}$ & & & $\begin{array}{l}\text { Müşterilerle } \\
\text { Çevresel } \\
\text { Yönetim-e33 }\end{array}$ \\
\hline $\begin{array}{l}\text { Çevresel } \\
\text { kazalar için } \\
\text { cezaların } \\
\text { düşmesi-O11 }\end{array}$ & $\begin{array}{l}\text { Tedarikçilerle } \\
\text { Lojistik } \\
\text { Bütünleşme-İ }\end{array}$ & $\begin{array}{l}\text { Müşterilerle } \\
\text { Lojistik } \\
\text { Bütünleşme- } \\
\text { B27 }\end{array}$ & $\begin{array}{l}\text { Tedarikçilerin } \\
\text { Çevresel } \\
\text { Yönetimi-D34 }\end{array}$ & & & $\begin{array}{l}\text { Müşterilerle } \\
\text { Çevresel } \\
\text { Yönetim-e34 }\end{array}$ \\
\hline $\begin{array}{l}\text { İşlemsel } \\
\text { Performans }\end{array}$ & $\begin{array}{l}\text { Tedarikçilerle } \\
\text { Lojistik } \\
\text { Bütünleşme-í5 }\end{array}$ & & $\begin{array}{l}\text { Tedarikçilerin } \\
\text { Çevresel } \\
\text { Yönetimi-D35 }\end{array}$ & & & $\begin{array}{l}\text { Müşterilerle } \\
\text { Çevresel } \\
\text { Yönetim-e35 }\end{array}$ \\
\hline \multicolumn{7}{|l|}{$\begin{array}{l}\text { İşletme } \\
\text { Perform. -O13 }\end{array}$} \\
\hline $\begin{array}{l}\text { İşletme } \\
\text { Perform. -O15 }\end{array}$ & & & & & & \\
\hline
\end{tabular}




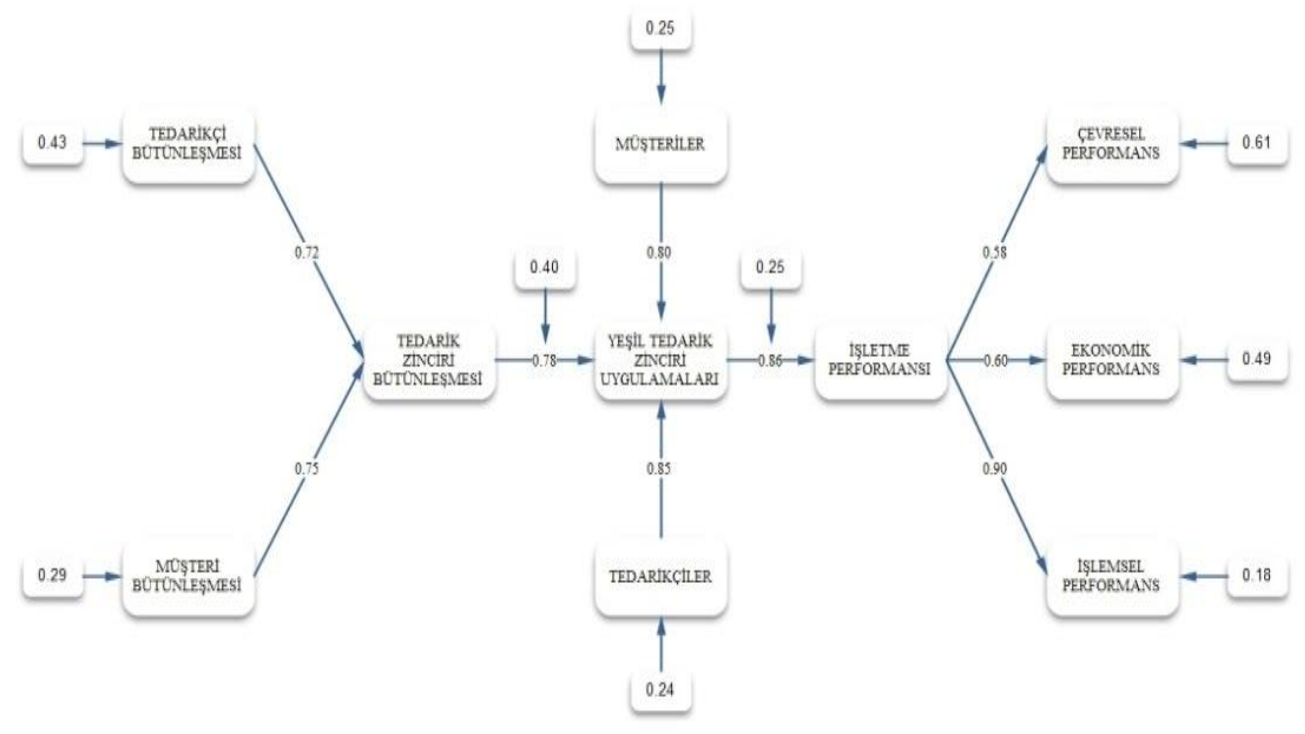

Şekil 2. Araştırma Modelinin Path Diyagramı

\section{SONUÇ VE ÖNERILER}

Araştırma modelinde yer alan ölçekler önce doğrulayıcı faktör analizi ile test edilmiş uyumsuzluk gösteren ölçeklerin daha sonra kalan değişkenleri ikincil doğrulayıcı faktör analizine tabi tutulmuştur. Bu analizler sonrası kalan değişkenlerin araştırma modeli, Path analizi ile test edilmiştir. Analiz sonucunda elde edilen değerler incelendiğinde modelin anlamlı olduğu belirlenmiş ve ölçeklerin kalan değişkenleri şu şekilde ifade edilmiştir.

Tedarikçilerle lojistik bütünleşme ölçeği test edilmiş; "Birincil tedarikçilerin ilerlemesine yardım edecek bilgiler sağlanmalı", "Birincil tedarikçilerle işlemsel ve lojistikle ilgili bilgi alış-verişinde bulunulmalı", "Önceden belirlenmiş bir anlaşma olmadan birincil tedarikçilerle gayri resmi olarak bilgi alış- verişinde bulunulmalı","Birincil tedarikçileri etkileyebilecek olan olay ve değişiklikler onlara bildirilmeli", "Birincil tedarikçilerle planlama yapma amacı ile yüz yüze iletişimde bulunulmalı" olmak üzere beş ifade kalmıştır. Bu ifadeler tedarikçilerle lojistik bütünleşme ölçeğinin daha çok bilgi paylaşımı sorularından oluştuğunu göstermektedir.

Tedarikçilerle teknolojik bütünleşme ölçeği test edilmiş," Performansın artmasına yardım etmek için tesisler ziyaret edilmeli", "Tatmin olmuş bir müşteri olmak için kendi çalışanlarını ve kaynaklarını tahsis etmeli", "Sattıkları ürünler hakkında eğitim vermeli", "Sipariş edilen ürünlerin kalitesini geliştirmek için beraber 
gayret göstermelidirler" olmak üzere dört ifade kalmıştır. Bu ifadeler tedarikçilerin teknolojik bütünleşme ölçeği sorularının daha çok kaliteyi ve performansı artırmaya yönelik sorulardan oluştuğunu göstermektedir. Müşterilerle kaynak bütünleşmesi ölçeği test edilmiş, "Personele eğitim imkanı sağlanmalı", "Performansın artmasına yardım etmek için tesisler ziyaret edilmeli", "Ürünlerin nasıl kullanıldığını göstermek için tesislere davet edilmeli", "Basım sürecine katılmalı ve basımın ilk aşamalarında yardımcı olmalıdırlar" olmak üzere dört ifade kalmıştır.

Müşterilerle lojistik bütünleşme ölçeği test edilmiş,"Mevcut ambalajlamadaki önemli dizayn değişiklikleriyle ilgili üretim konularını müzakere etmelidirler.", "Özel bir anlaşma olmadan gayri resmi olarak bilgi alış verişinde bulunulmalı", "Planlama yapma amacı ile yüz yüze iletişimde bulunulmalı", "Ürün sevkiyatı ile ilgili istekler de esnekliğe izin verilmeli" olmak üzere dört ifade kalmıştır. Bu ifadeler, tedarikçilerle lojistik bütünleşme konusundan farklı olarak dizayn ve sevkiyat ile ilgili konulardan oluşmaktadır.

Tedarikçilerin çevresel hareketleri ölçeği test edilmiş, "Çevre yönetimi ve teknolojilerindeki bilgi ve uzmanlıklar paylaşılmalı", "Daha fazla çevre dostu olan malzemeler kullanımına geçiş aşamasına yardımcı olunmalı", "Çevresel ambalajlama uygulamalarında işbirliği yapılmalı", "Çevresel pazarlama uygulamalarında işbirliği yapılmalı", "Ürün dizaynın da üretim sürecinde ki tehlikeli ürünlerin kullanımını azaltmak için işbirliği yapılmalı", "Ürün dizaynın da enerji tüketimini azaltmak için işbirliği yapılmalı" olmak üzere yeşil tedarik zinciri kavramı içinde düşünülen altı ifade kalmıştır.

Tedarikçilerle çevresel işbirliği ölçeği test edilmiş, "Çevresel hedefler ortaklaşa başarılmalı", "Faaliyetlerin çevreye olan etkisini azaltmak için birlikte çalışılmalı", "Çevreyle ilgili problemlerin tahmini ve çözümü için ortaklaşa planlama yapılmalı", "Ürünlerin çevresel etkilerini azaltmak için ortaklaşa karar verilmeli" olmak üzere tedarikçilerle yeşil tedarik zinciri uygulamalarını başarmak için dört ifade kalmıştır.

Tedarikçilerle çevresel yönetim ölçeği test edilmiş, "Tedarikçi seçimi kriterin de çevresel faktörleri dikkate alınmalı", "Tedarikçilere yazılı çevresel istekler bildirilmeli", "Tedarikçilere uygunluklarını gözlemlemek için çevreyle ilgili anketler yollanmalı", "Tedarikçilerin uygulanmakta olan çevresel yönetim sistemine sahip olmaları istenmeli", "Tedarikçilerin atık azaltma hedeflerine sahip olmaları istenmeli" olmak üzere beş ifade mevcuttur ve literatürden alınmış olan ölçeğin değişkenleri aynen kalmiştır.

Müşterilerin çevresel hareketleri ölçeği test edilmiş “Çevresel yönetim ve teknolojiler konusunda bilgi ve deneyimler paylaşılmalı", "Çevreye duyarlı malzeme alma sürecinde uzmanlık sağlanmalı", "Çevresel ambalajlama uygulamalarında işbirliği yapılmalı", "Ürün dizaynında üretim sürecindeki tehlikeli ürünlerin kullanımını azaltmak için işbirliği yapılmalı" olmak üzere dört ifade kalmıştır. Tedarikçilerin çevresel hareketlerinde çevresel pazarlama uygulamaları ve ürün dizaynı için enerji tüketimini azaltma önemli iken müşterilerin çevresel hareketleri için önem arz etmemektedir. Müşterilerle çevresel işbirliği ölçeği test edilmiş, "Çevresel 
hedefler ortaklaşa başarılmalı", "Çevresel performansla ilgili sorumlulukların karşılıklı mutabakatı geliştirilmeli", "Faaliyetlerin çevreye olan etkisini azaltmak için birlikte çalışılmalı", "Çevreyle ilgili problemlerin tahmini ve çözümü için ortaklaşa planlama yapılmalı", "Ürünlerin çevresel etkilerini azaltmak için ortaklaşa karar verilmeli" olmak üzere beş ifade kalmıştır. Tedarikçilerle çevresel işbirliğinde çevreye olan etkiyi azaltmak için beraber çalışmak önem arz ederken müşterilerle çevresel işbirliğinde çevresel performansla ilgili sorumlulukları birlikte çözmek önem arz etmektedir.

Müşterilerle çevresel yönetim ölçeği test edilmiş, "Tedarikçi seçimi kriterin de çevresel faktörleri dikkate alınmalı", "Tedarikçilere yazılı çevresel istekler bildirilmeli", "Tedarikçilere uygunluklarını gözlemlemek için çevreyle ilgili anketler yollanmalı", "Tedarikçilerin uygulanmakta olan çevresel yönetim sistemine sahip olmaları istenmeli", "Tedarikçilerin atık azaltma hedeflerine sahip olmaları istenmeli" olmak üzere beş ifade kalmıştır. Bu ifadeler tedarikçilerle çevresel yönetim ölçeğinde ki ifadelerle birebir örtüşmektedir.

Çevresel performans ölçeği test edilmiş, "Hava emisyonu azaltılmalı", "Su emisyonu azaltılmalı", "katı atıklar azaltılmalı", "işletmenin çevresel durumu geliştirilmeli" olmak üzere dört ifade kalmıştır. Ölçekten elenen çevresel kazaların sıklığı ve toksik madde, zararlı ve tehlikeli maddeler için tüketimin azaltılması ifadelerinin çevresel performansı etkilemediği tespit edilmiştir. Ekonomik performans ölçeği test edilmiş, "Enerji tüketimi için maliyetler düşürülmeli", "Atık boşaltımı için ücretler düşürülmeli", "Çevresel kazalar için cezalar düşürülmeli" olmak üzere üç ifade kalmıştır. Malzeme satın alımı için maliyetlerin düşürülmesi, Atıkları önlemek için ücretlerin düşürülmesi ve ürünlerin zamanında dağıtım miktarının artması ifadelerinin ekonomik performansı etkilemediği tespit edilmiştir. İşlemsel performans ölçeği test edilmiş, "Stok seviyesi düşürülmeli", "Ürün hattı artırılmalı" olmak üzere iki ifade kalmıştır. Ürün kalitesinin desteklenmesi ve kapasite kullanımının iyileştirilmesi ifadelerinin işlemsel performansı etkilemediği tespit edilmiştir. İşletme performansı ile boyutları arasında $\mathrm{ki}$ standart değerler incelendiğinde çevresel performans 0.58 , ekonomik performans 0.60 ve işlemsel performans 0.90 standart değere sahiptir. En yüksek değerin işlemsel performans ile işletme performansı arasında olduğu görülmektedir.

Yeşil tedarik zinciri ile boyutları arasındaki standart değerler incelendiğinde müşterilerin 0.80 , tedarikçilerin 0.85 standart değere sahip oldukları görülmektedir. Aralarında çok fark olmamakla birlikte tedarikçilerin yeşil tedarik zinciri uygulamaları ile daha yüksek değere sahip olduğu görülmektedir.

Araştırmadan elde edilen sonuçlara göre, işletmelere şu önerilerde bulunulabilir.

- İşletmeler çevresel performanslarını artırmak için hava emisyonlarını, su emisyonlarını ve katı atıklarını azaltmalıdırlar.

- Çevre ile ilgili faaliyetlerde tüketiciler, devlet ve işletmeler işbirliği içinde olmalıdırlar 
- Özellikle KOBI'ler kamu destekli araştırma ve geliştirme çalışmalarına ağırlık vermeli ve kamu finansal desteği ile ileri teknoloji yöntemler kullanmalıdırlar.

- İşletmeler temiz üretim ilkelerini benimsemeli, tükenebilir kaynaklar yerine çevreye zarar vermeyen yenilenebilir kaynaklar, geri dönüştürülebilen ya da yeniden kullanılabilen ürünler tercih edilmelidir.

\section{KAYNAKÇA}

Gonzalez-Benito, J., Gonzalez-Benito, O. (2005). Environmental Proactivity and Business Performance: An Empirical Analysis, Omega, 33, 1-15

Hervani, A., A., Helms, M., M., Sarkis, J. (2005). "Performance Measurement for Green Supply Chain Management". Bencmarking, 4(12), 330-352.

Kline,R.,B.(2005)." Principles and Practice of Structural Equation Modeling-Methodology in the Social Sciences". New York, USA: Guilford Pres.

Li, G., Yang,H., Sun,L., Sohal,A.S.(2009). “The Impact of IT Implementation on Supply Chain Integration and Performance". International Journal Production Economics, 120,125-138.

Lopez-Gamero, M.,D., Molina-Azorin, J. F., Claver- E.(2010). “The Potential of Environmental Regulation to Change Managerial Perception, Environmental Management, Competitiveness and Financial Performance". Journal of Cleaner Production, 18, 963-974.

Shang, K., Lu,C., Li,S. (2010)."A Taxonomy of Green Supply Chain Management Capability Among Electronics-Related Manufacturing Firms in Taiwan". Journal of Environmental Management ,91,1218-1226.

Vachon, S., Klassen, R.,D.(2006)."Green Project Partnership in the Supply Chain:the Case of the Package Printing İndustry". Journal of Cleaner Production, 14, 661-671.

Vachon,S. (2003). Green Supply Chain Practices:An Examination of their Antecedents and Performance Outcomes, London, Ontario, Canada: Doctor of Philosophy,the University of Western Ontario.

Zhu,Q.,Sarkis, J.(2004)."Relationships Between Operational Practices Performance Among Early Adopters of Green Supply Chain Management Practices in Chinese Manufacturing Enterprises". Journal of Operations Management, 22, 265-289. 